\title{
Peculiarity of the Cathodoluminescence of Alpha- Alumina Prepared by Calcination of Gibbsite Powder or Generated by Oxidation of a Metallic FeCrAl Alloy
}

\author{
Djelloul Abdelkader and Boumaza Abdecharif \\ Laboratoire des Structures, Propriétés et Interactions Inter Atomiques (LASPI'A) \\ Centre Universitaire de Khenchela 40000 \\ Algeria
}

\section{Introduction}

Most of metallic materials functioning at high temperature need to have oxidation resistance. This resistance can be achieved when the material develops, through oxidation, an oxide film which acts as a diffusion barrier while keeping a good adherence. In this respect, alpha alumina clearly acts as such. The oxides of aluminum have been the subject of many investigations because of their commercial importance and scientific interest. The thermal stability and optical properties of pure nanometer-sized alumina powder have received much attention because of their intrinsic interest and commercial value. Nanometer-sized alumina powders are widely applied today. One of its applications is in fluorescent lamps due to the absorption of ultraviolet light. In fact, it can also emit the light under excitation with a suitable wavelength. It is important to note that there are many works about alpha alumina using X-ray diffraction, but there is a need for a more detailed structural analysis. To achieve this more exhaustive structural characterization we have used the Rietveld refinement method and cathodoluminescence (CL) measurements.

CL spectroscopy is widely used as a contactless and relatively nondestructive method to provide microcharacterization of the optical and electronic properties of luminescent materials. Nevertheless, it is used comparatively rarely for the investigation of oxide semiconductor structures. The major advantage of CL spectroscopy in the case of such structures is that most of the anticipated products of oxidation are luminescent, and it is easy to get excitation across the bandgap of any dielectric with readily available electron beam voltages. The emission occurs for all the luminescent mechanisms present in the material.

Pure a- $\mathrm{Al}_{2} \mathrm{O}_{3}$ crystal is colorless and shows little absorption in the ultraviolet-visible (UVVis) range. But various impurities ( $\mathrm{Ti}, \mathrm{Mn}, \mathrm{Cr}$, and $\mathrm{Fe}$ ) even a trace level causes apparent absorptions which are attributed to various emission centers (Jheeta et al., 2006).

The colors arise from very minor amounts of impurity $\left(<1 \%\right.$ of the $\mathrm{Al}^{3+}$ replaced by other cations) because the $\mathrm{Al}_{2} \mathrm{O}_{3}$ structure apparently does not tolerate substitutions. However, 
these trace substitutions can cause intense colors. Ruby is red because of its $\mathrm{Cr}^{3+}$ content. Yellow sapphire owes its color to $\mathrm{Fe}^{3+}$. Blue sapphire derives its color from $\mathrm{Fe}^{2+}-\mathrm{Ti}^{4+}$ and $\mathrm{Fe}^{2+}-\mathrm{Fe}^{3+}$ intervalence charge transfer. Green sapphires contain a mixture of the blue and green colors.

Strong well-known ${ }^{2} E \rightarrow{ }^{4} A_{2}$ lines of $\mathrm{Cr}^{3+}(693 \mathrm{~nm})$ with a long decay time characterize their luminescence spectra. Besides that, much weaker narrow lines are present, which are connected with Cr-pairs and more complicated complexes. The $\mathrm{Mn}^{4+}$ ion is isoelectronic with $\mathrm{Cr}^{3+}$, i.e., both of them have the same electronic structure of the open shell $\left(3 \mathrm{~d}^{3}\right.$ configuration). Thus, the spectroscopic properties of $\mathrm{a}-\mathrm{Al}_{2} \mathrm{O}_{3}: \mathrm{Mn}^{4+}$ are similar to those of ruby $\left(\mathrm{a}-\mathrm{Al}_{2} \mathrm{O}_{3}: \mathrm{Cr}^{3+}\right)$. Octahedral $\mathrm{Mn}^{4+}\left(3 \mathrm{~d}^{3}\right)$ would be expected to show the $\mathrm{R}$-line fluorescence characteristic of isoelectronic $\mathrm{Cr}^{3+}$ and in approximately the same region. The dominate defects for the visible emission might be different for a-alumina powders formed by heating any of the hydrates of aluminium to a sufficiently high temperature.

In the presence of lattice defects, extra luminescence emissions can be observed in the ultraviolet (UV) region upon highly energetic excitation. The main intrinsic defects in the aalumina crystals are oxygen vacancies in different charge states: a neutral vacancy, a vacancy capturing one electron (a $\mathrm{F}^{+}$-center), and a vacancy capturing two electrons (a Fcenter) (Kislov et al., 2004; Michizono et al., 2007; Yu et al., 2002). The observed UV spectrum in a- alumina can be deconvoluted into two distinct sub-band components: an $\mathrm{F}^{+}-$ center band, located at around $3.8 \mathrm{eV}$, and a less intense F-center band, located at around 3.0 eV (Brewer et al., 1980; Boumaza \& Djelloul, 2010; Boumaza et al., 2010). Depending on the defect introduction method one can create also $\mathrm{F}_{2}$-centers, $\mathrm{F}_{2}^{+}$-centers and $\mathrm{F}_{2}^{2+}$-centers (double oxygen vacancy with four, three and two trapped electrons respectively). $\mathrm{a}_{-}-\mathrm{Al}_{2} \mathrm{O}_{3}$ crystals with defects in the oxygen sublattice are actively studied as promising storage materials (Kortov \& Milman, 1996). In this connection, it is interesting to study luminescence properties of the nanostructured aluminium oxide and compare them with analogous properties of crystalline samples.

In this chapter, we present X-ray diffraction (Rietveld analysis) and CL measurements of aalumina powders formed by calcination of gibbsite or generated by oxidation of a metallic $\mathrm{FeCrAl}$ alloy. The peculiarity of the cathodoluminescence under comparable conditions of a- alumina is discussed.

\section{Materials and experimental methods}

Gibbsite powder, $\mathrm{Al}_{2}(\mathrm{OH})_{6}$, from Prolabo (no 20 984.298) was used. The powder is made of platelet aggregates and was composed of $64.5-67 \% \mathrm{Al}_{2} \mathrm{O}_{3}$ and max.: $0.01 \% \mathrm{Fe}_{2} \mathrm{O}_{3}, 0.02 \% \mathrm{SO}_{4}$, $0.002 \%$ heavy metals (as $\mathrm{Pb}$ ), and $1.0 \%$ non precipitable by $\mathrm{NH}_{4} \mathrm{OH}$ (as $\mathrm{SO}_{4}$ ). The sample experienced an ignition loss of $33-34.5 \%$ at $1000{ }^{\circ} \mathrm{C}$ and had a purity grade of $99.7 \%$. Its average particle size $(20 \mu \mathrm{m})$ was due to the agglomeration of crystallites. The specific surface area of the original sample was $0.5 \mathrm{~m}^{2} / \mathrm{g}$.

The gibbsite platelets was calcined in ambient atmosphere $\left(\mathrm{pO}_{2}=0.21 \mathrm{~atm}\right)$ at $1573 \mathrm{~K}$. The cycle was as follows: heating up to an isothermal temperature at $5 \mathrm{~K} / \mathrm{min}$, maintaining for $24 \mathrm{~h}$ at the calcination temperature and fast cooling down to room temperature (air quench). The calcination temperature was maintained for 24 hours to obtain a well-crystallised product. 
The present work was performed on ferritic ODS commercial FeCrAlY alloy PM2000 (20 $w t \% \mathrm{Cr}, 5.8 \mathrm{wt} \% \mathrm{Al}, 0.5 \mathrm{wt} \% \mathrm{Ti}, 0.5 \mathrm{wt} \% \mathrm{Y}_{2} \mathrm{O}_{3}$ ). This alloy is an alumina-forming alloy. The specimens, with dimensions $25 \times 25 \times 5 \mathrm{~mm}^{3}$, are cut from a rolled plate. In the case of the PM2000, sample was oxidised in air at $1223 \mathrm{~K}$ for $72 \mathrm{~h}$. The thermogravimetric method (TG) and differential thermal analysis (DTA) data were recorded under a dry air flow with a heating rate of $10 \mathrm{~K} / \mathrm{min}$ in a SETARAM TGDTA92-16.18 thermal analyser. TG measurements were corrected for temperature-dependent buoyancy by subtracting the data of a measurement carried out on an inert sample. The crystalline structure of the sample was investigated by XRD using a PANalytical X'Pert Pro MRD diffractometer configured as follows: $\mathrm{Cu}$ tube operating at $40 \mathrm{kV}$ and $30 \mathrm{~mA}\left(\lambda\left(K a_{1}\right)=0.15406 \mathrm{~nm}, \lambda\left(K a_{2}\right)\right.$ $=0.15444 \mathrm{~nm})$. The scan rate $(2 \theta)$ was $1^{\circ} / \mathrm{min}$ at a step size of $0.025^{\circ}$. The data were processed to realize the conditions of the software program Fullprof Suite for the structure refinement.

The FTIR technique was used in the absorbance mode in the $200-4000 \mathrm{~cm}^{-1}$ range. For oxides all bands have characteristic frequencies between 200 and $1000 \mathrm{~cm}^{-1}$. For the FTIR measurements, samples were prepared by grinding the oxide films scraped from the substrate (PM2000). After calcination, 10 to $100 \mu \mathrm{g}$ of the powder was drawn, then grinded with $23 \pm 2 \mathrm{mg}$ of $\mathrm{CsBr}$ in order to obtain, a pellet of $200-250 \mu \mathrm{m}$ in thickness. After grinding, the powder was placed in a mould ( $5 \mathrm{~mm}$ diameter) and a cold isostatic pressure (CIP) of $150 \mathrm{MPa}$ was applied for $5 \mathrm{~min}$.

The FTIR spectra are obtained using a Perkin-Elmer spectrometer at resolution of $8 \mathrm{~cm}^{-1}$. For each sample, 120 scans were used. The apparatus is equipped with a system allowing the reduction of the optical course in air in order to minimize the perturbations associated with ambient air (water vapour and $\mathrm{CO}_{2}$ ). The uncertainty on the position of the various peaks is equal to $\pm 2 \mathrm{~cm}^{-1}$.

The emitted light under electron beam excitation in a UHV system was analyzed through a quartz window with a Jobin Yvon CP 2000 spectrograph and a CCD detector. The wavelength range 200-1000 $\mathrm{nm}$ was investigated.

\section{Results and discussions}

\subsection{Differential thermal analysis and thermal gravimetry analysis (DTA-TG) of gibbsite}

Fig. 1 shows the typical TG-DTA curves of the gibbsite. TG and DTA curves are indicated as dotted and solid lines, respectively. Concerning the dehydration-dehydroxylation process of gibbsite, the dehydration appears to occur in two steps (around 598 and $803 \mathrm{~K}$ respectively) at higher temperature. The expected theoretical loss due to dehydration is $34.6 \%$, the experimental loss is $34.3 \%$ a little lower. This difference $0.3 \%$ is a bit larger than the experimental uncertainty $0.1 \%$, the starting gibbsite may be slightly dehydrated. The last step ( 803 to $1273 \mathrm{~K}$ ) gives no thermal event but appears as a continuous mass loss (about $2 \%$ ) which corresponds to the elimination of residual hydroxyls. The formation of aalumina occurs between 1473 and 1533 K (MacKenzie et al., 1999). Finally, the structural transformations to well-crystallised a-alumina are described by nucleation $(\mathrm{T}<1470 \mathrm{~K})$ and growth mechanisms ( $\mathrm{T}>1470 \mathrm{~K})$. 


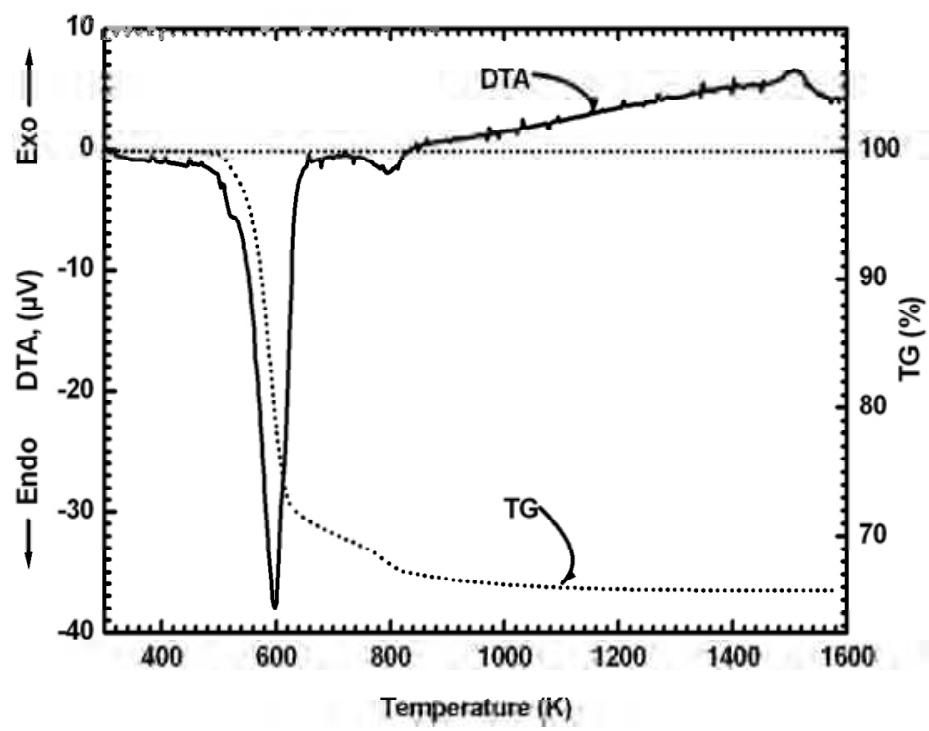

Fig. 1. TG and DTA curves of gibbsite.

\subsection{Gibbsite}

Gibbsite $\left(\gamma-\mathrm{Al}(\mathrm{OH})_{3}\right)$ has monoclinic symmetry $\left(a=0.8684, b=0.5078, c=0.9736 \mathrm{~nm}, \beta=94.54^{\circ}\right)$ with the space group $\mathrm{P} 21 / \mathrm{n}$, and the unit cell contains eight $\mathrm{Al}(\mathrm{OH})_{3}$ units (Saalfeld \& Wedde, 1974). Gibbsite is characterized by the stacking of two-layer units (AA or BB) of hydroxyl sheets with the sequence ABBAABBA... where hydroxyl sheets of the adjacent Gibbsite layers face the $c$ direction (Kogure, 1999). In Fig. 2a, the XRD pattern obtained on the as received gibbsite powder shows a good agreement with the reference XRD pattern (33-0018 JCPDS file).

\subsubsection{Phase transitions induced by heat treatment of gibbsite}

When heating up fine-grained gibbsite, most $\mathrm{OH}$ groups are eliminated, and various forms of alumina are formed with the sequence: gibbsite $\rightarrow \mathrm{x} \rightarrow \mathrm{K}-\rightarrow \mathrm{a}-\mathrm{Al}_{2} \mathrm{O}_{3}$ when temperature increases. In order to study these phases, we performed XRD measurements on four samples prepared from gibbsite calcined for $24 \mathrm{~h}$ at 773,1073 (62h), 1173 and $1573 \mathrm{~K}$ respectively.

According to Fig. $2 \mathrm{~b}$, at $773 \mathrm{~K}$, the $\chi$ phase is expected. In spite of many investigations since the1950's (Brindley \& Choe, 1961; Kogure, 1999; Saalfeld, 1960; Stumpf et al., 1950; Yu et al., 2002), the crystal structure of $\chi$-alumina is still uncertain. Stumpth et al. (Stumpf et al., 1950) assumed a cubic (not spinel) unit cell of lattice parameter $a=0.795 \mathrm{~nm}$ (04-0880 JCPDS file). On the other hand, two hexagonal structures have been suggested, either with the parameters $a=0.556 \mathrm{~nm}$ and $c=1.344 \mathrm{~nm}$ (Saalfeld, 1960) or with $a=0.557 \mathrm{~nm}$ and $c=0.864 \mathrm{~nm}$ (Brindley \& Choe, 1961) (13-0373 JCPDS file). The two previous hexagonal unit cells may be described respectively as a stacking of 6 and 4 close-packed oxygen layers, of approximately the same thickness $(0.224$ and $0.216 \mathrm{~nm})$ as the $\mathrm{Al}-\mathrm{OH}$ layers in gibbsite $(0.212 \mathrm{~nm})$. More 
recently, Kogure (Kogure, 1999) proposed a hexagonal lattice with $a=0.49 \mathrm{~nm}$ and an undefined $c$ length indicating that $\chi$-alumina structure can be regarded as random close packing of gibbsite-like layers.

For samples prepared at $1173 \mathrm{~K}$, the $\mathrm{K}$ phase is expected (see Fig. 2d). Contrary to the $X$ phase, the crystal structure of K-alumina is well known (see for example Ref. (Ollivier et al., 1997) and references therein). K-alumina is orthorhombic with the space group pna $2_{1}$ and results in ten independent atoms positions (four $\mathrm{Al}$ and six $\mathrm{O}$ ). The experimental XRD pattern at $1173 \mathrm{~K}$ is specific of a pure K-alumina (Fig. $2 \mathrm{~d}$ ). Nevertheless, the presence of remnant $\chi$-phase cannot be excluded as all the $\chi$ peaks also appear in $\mathrm{k}$ structure. Note that the experimental XRD patterns show well crystallized phases, in contrast with the $X$ phase.

Fig. 3 give SEM images and XRD patterns of gibbsite powder (a) after calcination at (b)- 773 K; (c)- $1073 \mathrm{~K}$; (d)- $1573 \mathrm{~K}$, for $24 \mathrm{~h}$.

When heating up at temperature above $1573 \mathrm{~K}$ for $24 \mathrm{~h}$, gibbsite transforms into a-alumina, the stable structure. The XRD pattern of the $1573 \mathrm{~K}$ sample (Fig. 6) shows that only a- $\mathrm{Al}_{2} \mathrm{O}_{3}$ is present when compared with 42-1468 JCPDS file. In this structure, tetrahedral $\mathrm{Al}^{3+}$ ions are no longer present and only $\mathrm{AlO}_{6}$ octahedron remain.
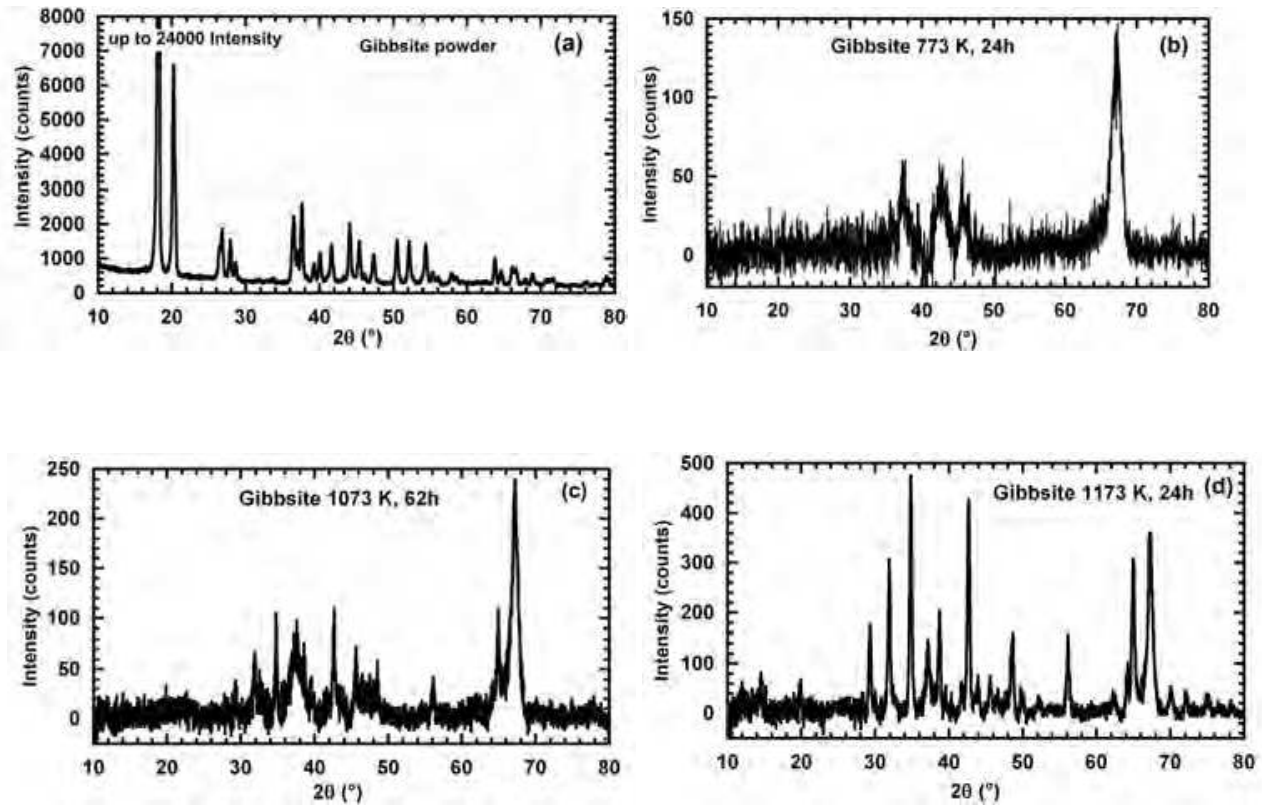

Fig. 2. XRD patterns: (a) Gibbsite (33-0018 JCPDS file), (b) alumina formed from gibbsite calcined for $24 \mathrm{~h}$ at $773 \mathrm{~K}$ (expected $\chi$ phase) (JCPDS 13-0373 file), (c) alumina formed from gibbsite calcined for $62 \mathrm{~h}$ at $1073 \mathrm{~K}$, (d) alumina formed from gibbsite calcined for $24 \mathrm{~h}$ at 1173K (expected $\mathrm{\kappa}$ phase) (JCPDS 88-0107 and 01-1305 file). 

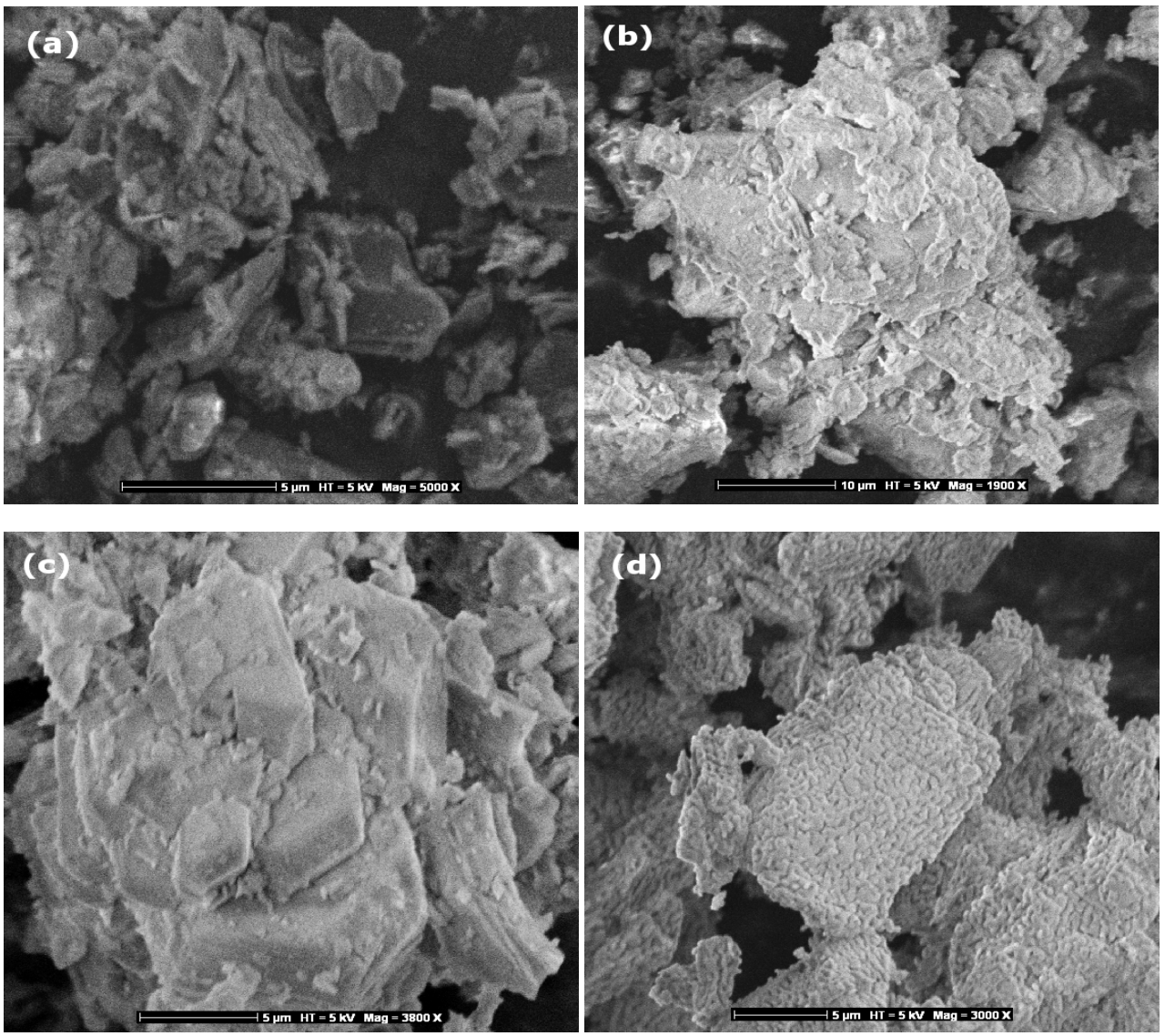

Fig. 3. SEM images: (a)- Gibbsite; (b)- 773 K; (c)- 1073 K; (d)- 1573 K.

\subsubsection{General properties of alumina $\left(\mathrm{Al}_{2} \mathrm{O}_{3}\right)$}

Aluminum oxide, commonly referred to as alumina, possesses strong ionic interatomic bonding giving rise to it's desirable material characteristics. It can exist in several crystalline phases which all revert to the most stable hexagonal alpha phase at elevated temperatures. This is the phase of particular interest for structural applications and the material available from Accuratus.

The exceptional properties of alumina $\left(\mathrm{Al}_{2} \mathrm{O}_{3}\right)$, such as great hardness, high thermal and chemical stability, and high melting temperature, make it a very attractive material. The crystalline $\mathrm{a}-\mathrm{Al}_{2} \mathrm{O}_{3}$ phase (corundum or sapphire) is the single stable modification of alumina. The crystalline $\mathrm{a}-\mathrm{Al}_{2} \mathrm{O}_{3}$ has the band gap $\mathrm{Eg} \approx 8.5 \mathrm{eV}$ and is widely used in optical devices. Sapphire doped with chrome (ruby) or titanium is applied as an active medium in laser systems. In microelectronics sapphire is used as a substrate for growing silicon and gallium nitride $(\mathrm{GaN})$. Alumina is a highly radiation-resistant material and is used as a sensitive element in detectors when measuring the ionizing radiation parameters. 
High purity alumina is usable in both oxidizing and reducing atmospheres to $1925^{\circ} \mathrm{C}$. Weight loss in vacuum ranges from $10^{-7}$ to $10^{-6} \mathrm{~g} / \mathrm{cm}^{2} . \mathrm{sec}$ over a temperature range of $1700^{\circ}$ to $2000^{\circ} \mathrm{C}$. It resists attack by all gases except wet fluorine and is resistant to all common reagents except hydrofluoric acid and phosphoric acid. Elevated temperature attack occurs in the presence of alkali metal vapors particularly at lower purity levels.

The composition of the ceramic body can be changed to enhance particular desirable material characteristics. An example would be additions of chrome oxide or manganese oxide to improve hardness and change color. Other additions can be made to improve the ease and consistency of metal films fired to the ceramic for subsequent brazed and soldered assembly.

Mechanical, thermal and electrical properties of $\mathrm{Al}_{2} \mathrm{O}_{3}$ are summarized in table 1 .

\begin{tabular}{|c|c|c|c|c|}
\hline & Units of Measure & $94 \% \mathrm{Al}_{2} \mathrm{O}_{3}$ & $96 \% \mathrm{Al}_{2} \mathrm{O}_{3}$ & $99.5 \% \mathrm{Al}_{2} \mathrm{O}_{3}$ \\
\hline \multicolumn{5}{|l|}{ Mechanical } \\
\hline Density & $\mathrm{gm} / \mathrm{cc}$ & 3.69 & 3.72 & 3.89 \\
\hline Porosity & $\%$ & 0 & 0 & 0 \\
\hline Color & - & white & white & ivory \\
\hline Flexural Strength & $\mathrm{MPa}$ & 330 & 345 & 379 \\
\hline Elastic Modulus & $\mathrm{GPa}$ & 300 & 300 & 375 \\
\hline Shear Modulus & $\mathrm{GPa}$ & 124 & 124 & 152 \\
\hline Bulk Modulus & $\mathrm{GPa}$ & 165 & 172 & 228 \\
\hline Poisson's Ratio & - & 0.21 & 0.21 & 0.22 \\
\hline $\begin{array}{l}\text { Compressive } \\
\text { Strength }\end{array}$ & $\mathrm{MPa}$ & 2100 & 2100 & 2600 \\
\hline Hardness & $\mathrm{Kg} / \mathrm{mm}^{2}$ & 1175 & 1100 & 1440 \\
\hline $\begin{array}{l}\text { Fracture } \\
\text { Toughness } \mathrm{K}_{\mathrm{IC}}\end{array}$ & $\mathrm{MPa} \bullet \mathrm{m}^{1 / 2}$ & 3.5 & 3.5 & 4 \\
\hline $\begin{array}{l}\text { Maximum Use } \\
\text { Temperature }\end{array}$ & ${ }^{\circ} \mathrm{C}$ & 1700 & 1700 & 1750 \\
\hline \multicolumn{5}{|l|}{ Thermal } \\
\hline $\begin{array}{l}\text { Thermal } \\
\text { Conductivity }\end{array}$ & $\mathrm{W} / \mathrm{m} \bullet \mathrm{K}$ & 18 & 25 & 35 \\
\hline $\begin{array}{l}\text { Coefficient of } \\
\text { Thermal } \\
\text { Expansion }\end{array}$ & $10^{-6} /{ }^{\circ} \mathrm{C}$ & 8.1 & 8.2 & 8.4 \\
\hline Specific Heat & $\mathrm{J} / \mathrm{Kg} \bullet \mathrm{K}$ & 880 & 880 & 880 \\
\hline \multicolumn{5}{|l|}{ Electrical } \\
\hline $\begin{array}{l}\text { Dielectric } \\
\text { Strength } \\
\end{array}$ & $\mathrm{ac}-\mathrm{kV} / \mathrm{mm}$ & 16.7 & 14.6 & 16.9 \\
\hline $\begin{array}{l}\text { Dielectric } \\
\text { Constant }\end{array}$ & At $25^{\circ} \mathrm{C}, 1 \mathrm{MHz}$ & 9.1 & 9.0 & 9.8 \\
\hline $\begin{array}{l}\text { Dissipation } \\
\text { Factor }\end{array}$ & At $25^{\circ} \mathrm{C}, 1 \mathrm{MHz}$ & 0.0007 & 0.0011 & 0.0002 \\
\hline $\begin{array}{l}\text { Volume } \\
\text { Resistivity }\end{array}$ & $\mathrm{Ohm} \bullet \mathrm{cm}$ & $>10^{14}$ & $>10^{14}$ & $>10^{14}$ \\
\hline
\end{tabular}

Table 1. Mechanical, thermal and electrical properties of $\mathrm{Al}_{2} \mathrm{O}_{3}$ (http:/ /accuratus.com/alumox.html). 


\subsubsection{Oxidation of PM2000}

The oxidation resistance of high-temperature alloys and metallic coatings is dependent on the formation of a protective surface oxide. In an ideal case, the oxide layer should be highly stable, continuous, slow growing, free from cracks or pores, adherent and coherent. $\mathrm{a}-\mathrm{Al}_{2} \mathrm{O}_{3}$ is an oxide which comes close to satisfying these requirements; the slow growth rate is related to its highly stoichiometric structure and its large band gap which makes electronic conduction difficult.

One of the most crucial factors in the oxidation of alumina-formers is the temperature, which must be high enough to promote the formation of $a-\mathrm{Al}_{2} \mathrm{O}_{3}$ in preference to the less protective transition alumina. Another critical factor is the aluminum content which must be sufficiently high to develop and maintain an alumina layer and prevent subsequent breakaway oxidation.

The addition of chromium to Fe-Al alloys promotes the formation and maintenance of a complete layer of a- $\mathrm{Al}_{2} \mathrm{O}_{3}$ by acting as a getter and preventing internal oxidation of the aluminum (Wood, 1970).

Iron and chromium are the major impurities present in $\mathrm{Al}_{2} \mathrm{O}_{3}$ scales formed on PM2000. Primarily their oxides formed during the transient stage and were incorporated into the $\mathrm{a}-\mathrm{Al}_{2} \mathrm{O}_{3}$ scale. Fe segregated to some $\mathrm{a}-\mathrm{Al}_{2} \mathrm{O}_{3}$ grain boundaries, but not $\mathrm{Cr}$. The $\mathrm{Al}_{2} \mathrm{O}_{3}$ scale became progressively purer with oxidation time. It is possible that the $\mathrm{Fe}$ in the $\mathrm{Al}_{2} \mathrm{O}_{3}$ scale increases the scaling rate and, in particular, enhances lateral growth that causes scale convolution.

The growth of $\mathrm{a}-\mathrm{Al}_{2} \mathrm{O}_{3}$ scales that form on $\mathrm{FeCrAl}$ alloys during high temperature oxidation is generally considered to be controlled by oxygen inward diffusion through oxide grain boundaries (Mennicke et al., 1998; Quaddakkers et al., 1991). Aluminum also diffuses out, which can cause growth within the scale (Golightly et al., 1979). The degree of Al outward transport can be significantly reduced by the presence of reactive elements, such as $\mathrm{Y}$, Hf or $\mathrm{Zr}$ (Mennicke et al., 1998; Quaddakkers et al., 1991), which segregate to $\mathrm{Al}_{2} \mathrm{O}_{3}$ grain boundaries (Przybylski et al., 1987). However, the extent of outward growth seems to differ appreciably among several reactive-element doped Fe based alloys.

The EDS results of the average Fe and $\mathrm{Cr}$ concentrations in the scale as a function of scale thickness from different transmission electron microscopy (TEM) specimens are summarized in Table 2.

\begin{tabular}{|c|c|c|c|c|c|}
\hline $\begin{array}{l}\text { Oxidation } \\
\text { condition }\end{array}$ & $\begin{array}{c}\text { Scale } \\
\text { thickness } \\
(\mu \mathrm{m})\end{array}$ & $\begin{array}{l}\text { Oxide grain } \\
\text { size }(\mathrm{nm})\end{array}$ & $\begin{array}{c}\text { Average }[\mathrm{Cr}] \\
(\mathbf{a t} \%)\end{array}$ & $\begin{array}{c}\text { Average }[\mathrm{Fe}] \\
(\mathrm{at} \%)\end{array}$ & $\begin{array}{c}\text { Lattice } \\
\text { parameter }(\mathrm{nm})\end{array}$ \\
\hline $1000^{\circ} \mathrm{C}, 0.5 \mathrm{~h}$ & 0.39 & $107 \pm 36$ & $4.12 \pm 0.95$ & $4.49 \pm 1.67$ & $\begin{array}{c}a=0.495 \pm 0.004 \\
c=1.353 \pm 0.008\end{array}$ \\
\hline $1000^{\circ} \mathrm{C}, 1 \mathrm{~h}$ & 0.9 & $191 \pm 44$ & $0.34 \pm 0.28$ & $1.91 \pm 0.49$ & \multirow{2}{*}{$\begin{array}{c}a=0.475 \pm 0.004 \\
c=1.347 \pm 0.008\end{array}$} \\
\hline $1000^{\circ} \mathrm{C}, 26 \mathrm{~h}$ & 1.77 & $186 \pm 53$ & $0.24 \pm 0.28$ & $0.60 \pm 0.32$ & \\
\hline $1200^{\circ} \mathrm{C}, 2 \mathrm{~h}$ & 2.94 & $291 \pm 46$ & $0.3 \pm 0.64$ & $0.70 \pm 0.57$ & \multirow{2}{*}{$\begin{array}{c}a=0.471 \pm 0.004 \\
c=1.323 \pm 0.008\end{array}$} \\
\hline $1200^{\circ} \mathrm{C}, 120 \mathrm{~h}$ & $4-5.5$ & $1546 \pm 423$ & $0.27 \pm 0.20$ & $0.06 \pm 0.06$ & \\
\hline
\end{tabular}

Standard parameters for $\mathrm{a}-\mathrm{Al}_{2} \mathrm{O}_{3}$ are: $a=0.4758 \mathrm{~nm}, c=1.2991 \mathrm{~nm}$.

Table 2. Fe and $\mathrm{Cr}$ concentrations in $\mathrm{a}-\mathrm{Al}_{2} \mathrm{O}_{3}$ scales and effect on lattice parameters (Hou et al., 2004) 
Fig. 4 give SEM images and XRD patterns of PM2000 after oxidation at $1023 \mathrm{~K}$ for $76 \mathrm{~h}$ and $1223 \mathrm{~K}$ for $72 \mathrm{~h}$.

EDX analysis (Fig. 5) of the sample oxidized at $1123 \mathrm{~K}$ indicates that the film mainly consists in aluminium and oxygen elements and very small amount of the substrate constituting elements are observed. As the film thickness decreases, like sample oxidized at $1023 \mathrm{~K}$, the signature of the substrate increases due to interactions of the electrons with the underlying substrate mater as the film is thinner than that formed at $1123 \mathrm{~K}$.
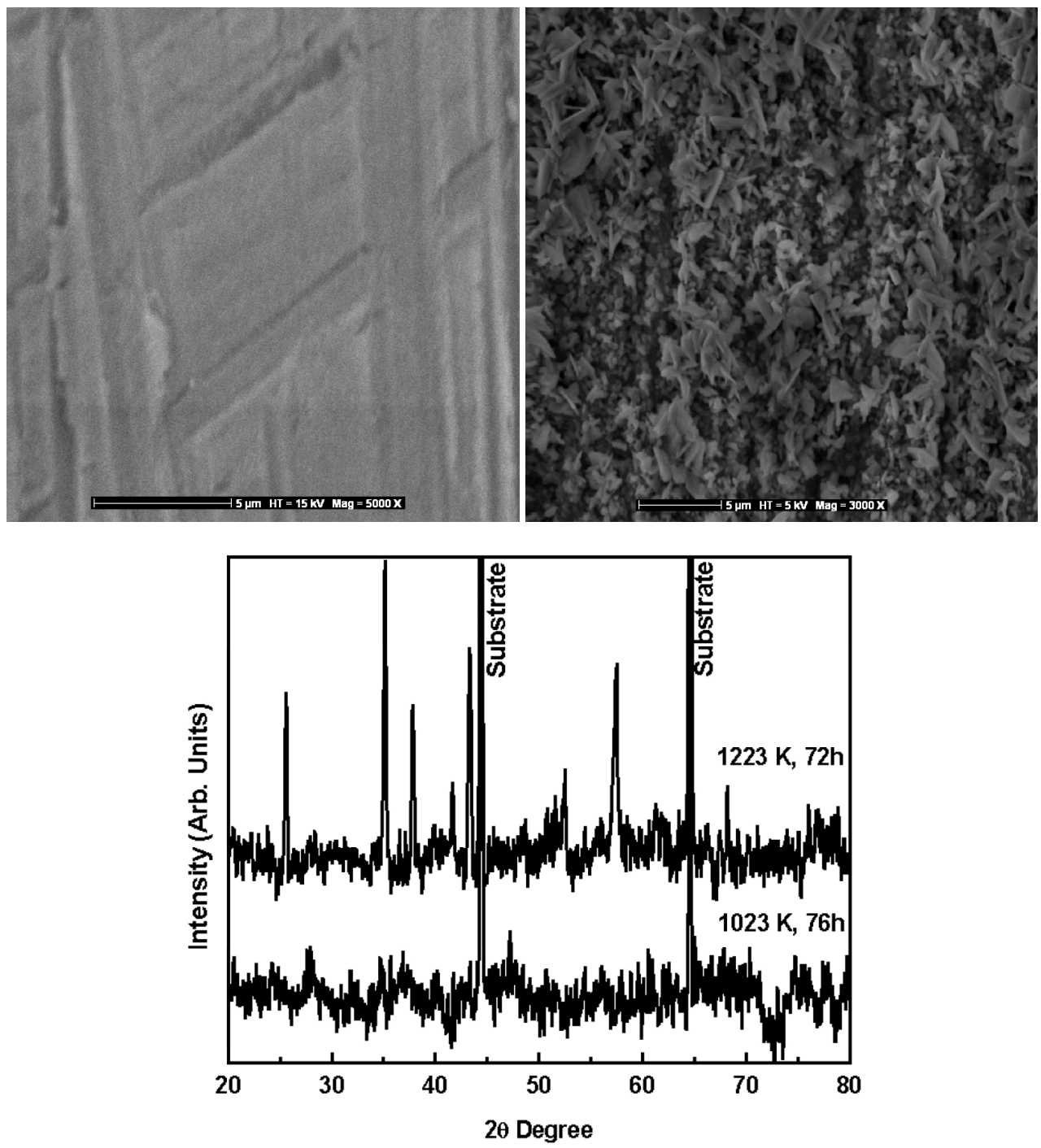

Fig. 4. SEM images of the outer oxidized surface and XRD patterns of $a-\mathrm{Al}_{2} \mathrm{O}_{3}$ obtained by oxidation of PM2000 at $1023 \mathrm{~K}$ for $76 \mathrm{~h}$ and $1223 \mathrm{~K}$ for $72 \mathrm{~h}$. 

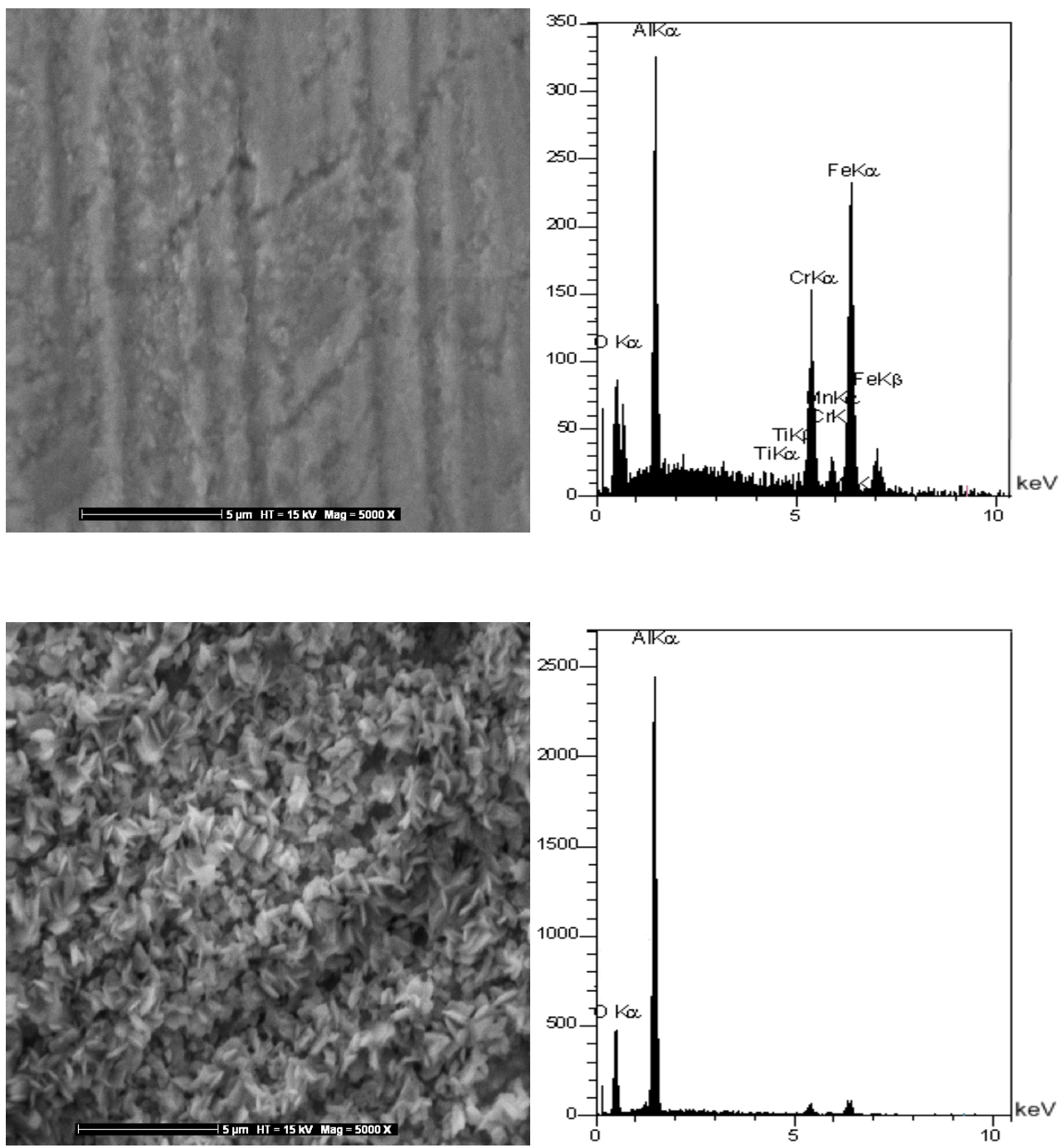

Fig. 5. SEM images of the outer surface and EDX analyses of a- $\mathrm{Al}_{2} \mathrm{O}_{3}$ films obtained by oxidation of PM2000 in air at $1023 \mathrm{~K}$ for $76 \mathrm{~h}$ (top) and $1123 \mathrm{~K}$ for $95 \mathrm{~h}$ (bottom). 


\subsubsection{Rietveld refinement of the structures}

The Rietveld refinement of the structures was performed using the WinPlotr/FullProf suite package (Rodríguez-Carvajal, 1993). The peak shape was described by a pseudo-Voigt function, and the background level was modeled using a polynomial function. The profiles were refined using the space group and structure models of $\mathrm{Al}_{2} \mathrm{O}_{3}$ ( $R \overline{3} \mathrm{C}$, JCPDS 46-1212) (in this structure cations occupy the $12 \mathrm{c}$ sites and oxygen ions the 18e sites).

The XRD data for the $2 \theta$ regions between $20^{\circ}$ and $80^{\circ}$ was used for the refinement. The observed, Rietveld refined and difference patterns are shown in Figs. 6 and 7.

It was obvious that the agreement between the experimental data and the simulations was excellent since the $R_{w p}$ (weighted residual error) factor was small $(\leq 14.1 \%$ ). The Rietveld results (cell parameters, atom position, reliability factors and crystallite size $(D)$ ) are given in Table 3 and 4 . The size of a-alumina crystallites $(D=36 \mathrm{~nm})$ obtained using PM2000 alloy was smaller than that $(D=43 \mathrm{~nm})$ obtained using gibbsite precursor. Furthermore, the a$\mathrm{Al}_{2} \mathrm{O}_{3}$ from PM2000 has a greater lattice parameter $(a=0.4763 \mathrm{~nm}, c=1.3047 \mathrm{~nm})$ than that of JCPDS file 46-1212 $(a=0.4758 \mathrm{~nm}, c=1.2991 \mathrm{~nm}, c / a=2.730)$ and a greater $c / a$ ratio $(c / a$ $=2.739)$ than that of JCPDS file 46-1212. However, the $a-\mathrm{Al}_{2} \mathrm{O}_{3}$ from gibbsite has a smaller lattice parameter $(a=0.4752 \mathrm{~nm}, c=1.2980 \mathrm{~nm})$ and a similar $c /$ a ratio $(c / a=2.731)$ than that of JCPDS file 46-1212. Furthermore, the $\mathrm{a}-\mathrm{Al}_{2} \mathrm{O}_{3}$ from gibbsite has a greater calculated density $\left(3.996 \mathrm{~g} / \mathrm{cm}^{3}\right)$ than that of $\mathrm{a}-\mathrm{Al}_{2} \mathrm{O}_{3}$ from PM2000 $\left(3.961 \mathrm{~g} / \mathrm{cm}^{3}\right)$. Phase transformations are frequently accompanied by microstructural changes. This fact could explain the crystallographic parameters differences between a two a-alumina.

\begin{tabular}{|l|l|l|l|l|l|l|l|l|}
\hline $\begin{array}{l}\text { Lattice parameters } \\
(\mathrm{nm})\end{array}$ & atom & Wyck. & Site & $x$ & $y$ & $z$ & Biso & occupancy \\
\hline $\begin{array}{l}a=0.47523 \\
c=1.29805\end{array}$ & Al & $12 \mathrm{c}$ & 3. & 0 & 0 & 0.3521 & 0.2200 & 0.3333 \\
\cline { 2 - 8 } & $\mathbf{O}$ & $18 \mathrm{e}$ & .2 & 0.3065 & 0 & 0.2500 & 0.2400 & 0.5000 \\
\hline
\end{tabular}

Table 3. The Rietveld refinement results: $\mathrm{a}-\mathrm{Al}_{2} \mathrm{O}_{3}$ from gibbsite powder, $\mathrm{R}_{\mathrm{p}}=16.7 \%$, $\mathrm{R}_{\mathrm{wp}}=6.93 \%$, Calc. density $=3.996 \mathrm{~g} / \mathrm{cm}^{3}, D=43 \mathrm{~nm}$.

\begin{tabular}{|l|l|l|l|l|l|l|l|l|}
\hline $\begin{array}{l}\text { Lattice parameters } \\
(\mathrm{nm})\end{array}$ & atom & Wyck. & Site & $x$ & $y$ & $z$ & Biso & occupancy \\
\hline $\begin{array}{l}a=0.47637 \\
c=1.30472\end{array}$ & Al & $12 \mathrm{c}$ & 3. & 0 & 0 & 0.3417 & 4.7208 & 0.9602 \\
\cline { 2 - 8 } & O & $18 \mathrm{e}$ & .2 & 0.3392 & 0 & 0.2500 & 2.7191 & 1.1186 \\
\hline
\end{tabular}

Table 4. The Rietveld refinement results: $\mathrm{\alpha}-\mathrm{Al}_{2} \mathrm{O}_{3}$ from $\mathrm{PM} 2000, \mathrm{R}_{\mathrm{wp}}=14.1 \%$, Calc. density $=3.961 \mathrm{~g} / \mathrm{cm}^{3}, D=36 \mathrm{~nm}$. 


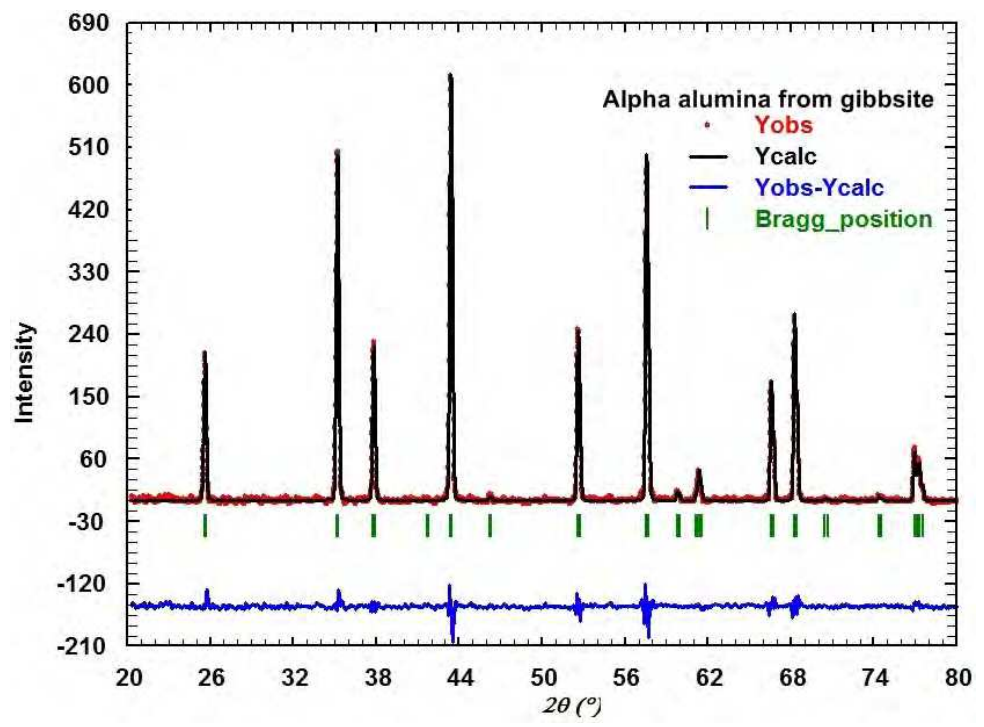

Fig. 6. The observed and calculated diffraction patterns of a-alumina powder prepared by calcination at $1573 \mathrm{~K}$ for $24 \mathrm{~h}$ of gibbsite powder. Vertical bars indicate the calculated position of the Bragg peaks. The blue curves in the bottom correspond to the differences between experimental and calculated profiles.

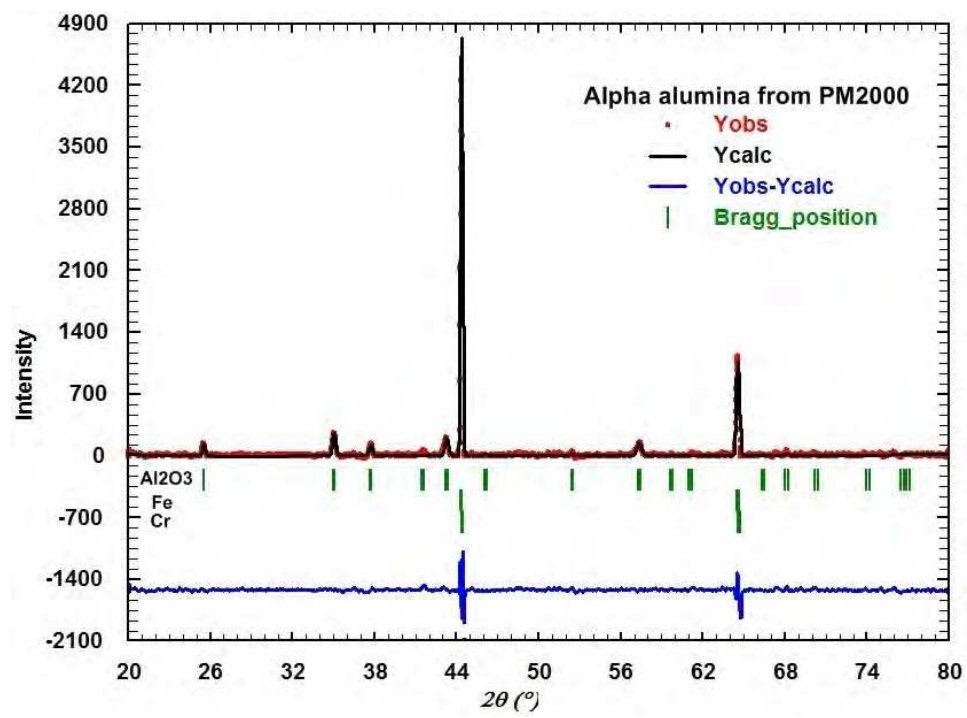

Fig. 7. The observed and calculated diffraction patterns of a-alumina obtained by oxidation of PM2000 at $1223 \mathrm{~K}$ for $72 \mathrm{~h}$. 


\subsubsection{Fourier transform infrared (FTIR) analysis}

Fig. 8 compares the FTIR absorbance spectra of $\mathrm{a}-\mathrm{Al}_{2} \mathrm{O}_{3}$ obtained after calcination of gibbsite and oxidation of PM2000. For the samples calcined at $1573 \mathrm{~K}$, significant spectroscopic bands at $\sim 640, \sim 594, \sim 447 \mathrm{~cm}^{-1}$ and $\sim 386 \mathrm{~cm}^{-1}$ appear which are identified to be the characteristic absorption bands of $\mathrm{a}^{-} \mathrm{Al}_{2} \mathrm{O}_{3}$ (Barker, 1963). This is in good agreement with XRD observations. Common bands exist in all cases, such as the broad $\mathrm{OH}$ band centered around $3420 \mathrm{~cm}^{-1}$, and the $1640 \mathrm{~cm}^{-1} \mathrm{H}_{2} \mathrm{O}$ vibration band (Ma et al., 2008). The very high surface area of these materials results in rapid adsorption of water from the atmosphere because the FTIR samples were kept and grinded in air. Three peaks of very weak intensities at $2850 \mathrm{~cm}^{-1}, 2920 \mathrm{~cm}^{-1}$ and $2960 \mathrm{~cm}^{-1}$ are observed which are due to C-H stretching vibrations of alkane groups. The absorption in $\sim 2356 \mathrm{~cm}^{-1}$ is due to $\mathrm{CO}_{2}$ molecular presence in air.

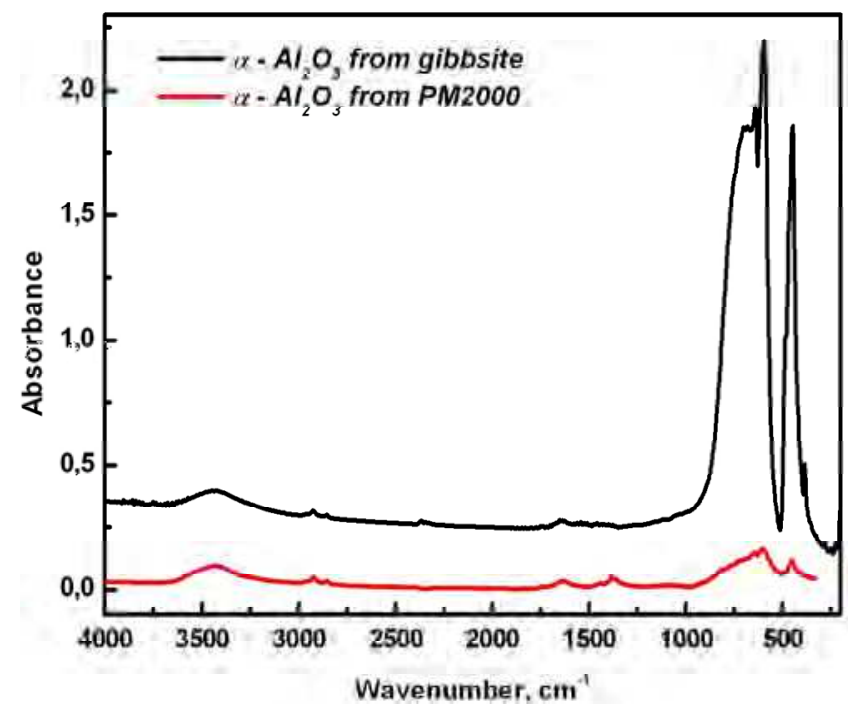

Fig. 8. FTIR absorption spectra of a-alumina powder prepared by calcination of gibbsite (black line) or generated by oxidation of PM2000 (red line).

\subsection{Cathodoluminescence}

$\mathrm{CL}$ is the phenomenon of light emission from specimens as a result of interaction with an electron beam. In insulating crystals, the origin of the luminescence arises from impurity atoms (e.g. transition metals or rare earths) in the crystal lattice. Using an electron microscope to produce the electron beam, the spatial distribution of luminescent sites can be observed with submicron spatial resolution, and correlated with features of the specimen morphology or microstructure.

The mechanisms for CL are similar to those for photoluminescence, but the energy input or excitation source is that of an electron beam rather than a visible or ultraviolet light beam. When an energetic ( $\mathrm{keV}$ range) electron beam propagates within a semiconductor or insulator, the primary electrons lose energy by the creation of electron-hole pairs. These 
electron-hole pairs then recombine via radiative and non-radiative processes. Only the radiative recombination process which leads to the creation of a photon is viewed with CL. Radiative recombination may be intrinsic (arising from electronic states of the perfect crystal) or extrinsic (arising from electronic states that are localized at defects or impurities in the crystal). Extrinsic luminescence thus provides information about defects and impurities in the crystal lattice. For conciseness, the defects and impurities that give rise to extrinsic luminescence are often denoted the luminescence centers. Each type of luminescence center in a particular crystal has a characteristic emission spectrum. The spectrum may contain both narrow lines and broad bands, depending on the energy level structure of the luminescence center and the coupling of the center to the host lattice. CL is advantageous compared to photoluminescence. CL can potentially give additional information about local positions in the sample because the electron beam can be focused on several nanometers. In addition, the CL system operates under UHV conditions of less than $10^{-9}$ Torr. Hence, CL measurements can be performed in a contamination-free environment, which is very effective in detecting weak luminescence. Moreover, the depth dependent emission profiles can be examined in CL by controlling the accelerating voltage.

\subsubsection{Oxygen vacancy in $\mathrm{Al}_{2} \mathrm{O}_{3}$}

CL signal is a good signature of the material qualities and is used in this study to characterize the point defects associated to oxygen vacancies in $\mathrm{a}-\mathrm{Al}_{2} \mathrm{O}_{3}$. The CL spectra of $\mathrm{a}-\mathrm{Al}_{2} \mathrm{O}_{3}$ formed from gibbsite and PM2000 are given in figure 9 and 12.

In figure 9, the CL spectra shows that wide band over the interval of (200-600 nm) consists of a series of overlapping bands. The main emission bands located at about $250 \mathrm{~nm}(4.96$ $\mathrm{eV}), 281 \mathrm{~nm}(4.41 \mathrm{eV}), 325 \mathrm{~nm}(3.81 \mathrm{eV}), 373 \mathrm{~nm}(3.32 \mathrm{eV})$ and $487 \mathrm{~nm}(2.54 \mathrm{eV})$ occur in alpha alumina powder and also in alpha alumina films generated by oxidation of a metallic FeCrAl alloy. We believe that the observed CL peak at $4.96 \mathrm{eV}$ is related to the interband transitions or to defect that is different in origin to the $\mathrm{F}$ or $\mathrm{F}^{+}$centers in a-alumina. The luminescence band at $4.41 \mathrm{eV}$ is detected only if the excitation density is high and was previously observed in a-alumina by Kortov et al. (Kortov et al., 2008).

In $\mathrm{a}-\mathrm{Al}_{2} \mathrm{O}_{3}$ (corundum structure) each $\mathrm{O}$ atom is surrounded by four $\mathrm{Al}$ atoms forming two kinds of Al-O bonds of length 0.186 and $0.197 \mathrm{~nm}$. This is why in corundum F-type centers have low $\mathrm{C}_{2}$ symmetry. Besides, an $\mathrm{O}$ vacancy has two nearest neighbor $\mathrm{O}$ atoms, forming the basic $\mathrm{O}$ triangle with $\mathrm{O}-\mathrm{O}$ band length of $0.249 \mathrm{~nm}$ in perfect corundum. Thus, the Ftype centers are surrounded by six nearest atoms which determine mainly their optical properties.

Defects induced in $\mathrm{Al}_{2} \mathrm{O}_{3}$ may be of various kinds: $\mathrm{F}$ centers (oxygen vacancy with two electron), $\mathrm{F}^{+}$centers (oxygen vacancy with one electron), $\mathrm{F}_{2}$ centers (two oxygen vacancies with four trapped electrons), $F_{2}^{+}$centers (two oxygen vacancies with three electrons) and $F_{2}^{2+}$ centers (two oxygen vacancies with two electrons) (Ghamdi \& Townsend, 1990).

In the case of a-alumina and sapphire, there have been reported a number of F-type centers including the $\mathrm{F}^{+}$and $\mathrm{F}$ centers (Evans, 1995). As for the luminescence of irradiation defects, it is known that the luminescence of the $\mathrm{F}^{+}$center is observed at the $\mathrm{UV}$ region around 3.8 
$\mathrm{eV}(325 \mathrm{~nm})$ while that of the F centers is observed at a lower photon energy region around $3.0 \mathrm{eV}(410 \mathrm{~nm})$. Thus the presently observed luminescence from a-alumina and sapphire which is centered at 330 and $420 \mathrm{~nm}$ can be attributed to the $\mathrm{F}^{+}$and $\mathrm{F}$ centers. As for the others, it is noted that the luminescence at 250 and $290 \mathrm{~nm}$ is also observed in the case of aalumina. The luminescence intensity at these bands was found to be sensitive to thermal annealing at higher temperatures, and then might be attributed to the effect of some impurities such as $\mathrm{OH}$.

In Ref. (Oster \& Weise, 1994), the absorption bands of 220 and $260 \mathrm{~nm}$ in pure $\mathrm{a}-\mathrm{Al}_{2} \mathrm{O}_{3}$ crystals have been attributed to $\mathrm{F}+$ absorption bands. Due to the presence of $\mathrm{C}_{2}$-symmetry in the $\mathrm{F}^{+}$-center (oxygen vacancy occupied by a single electron) in pure $\mathrm{a}-\mathrm{Al}_{2} \mathrm{O}_{3}$ crystals, the excited state is split into three levels, ${ }^{1} \mathrm{~B},{ }^{2} \mathrm{~A}$, and ${ }^{2} \mathrm{~B}$, according to the theory of La et al. (La et al., 1973), giving three polarized optical absorption bands located at 255, 229 and $200 \mathrm{~nm}$.

The optical properties of these luminescent centres are well known. They possess absorption and emission bands which are produced in the gap as summarised in Fig. 10. F+ centre is characterised by three absorption bands at $6.3,5.4$ and $4.8 \mathrm{eV}$ and emits at $3.8 \mathrm{eV}(330 \mathrm{~nm})$. F centre absorbs at $6 \mathrm{eV}$ and emits at $3 \mathrm{eV}(415 \mathrm{~nm})$.

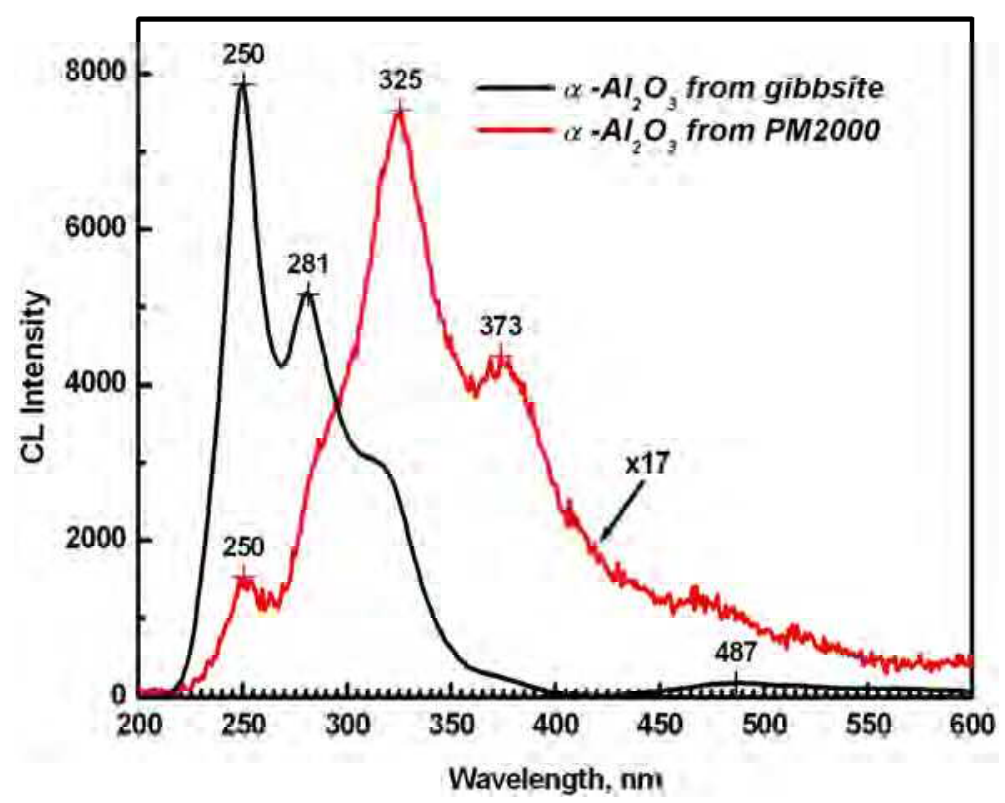

Fig. 9. CL spectra of $\mathrm{a}-\mathrm{Al}_{2} \mathrm{O}_{3}$, formed by calcination of gibbsite powder at $1573 \mathrm{~K}$ for $24 \mathrm{~h}$ (black line) and by oxidation of PM2000 at 1223K for 72h (red line), obtained in the region of 200 to $600 \mathrm{~nm}$ at room temperature. 


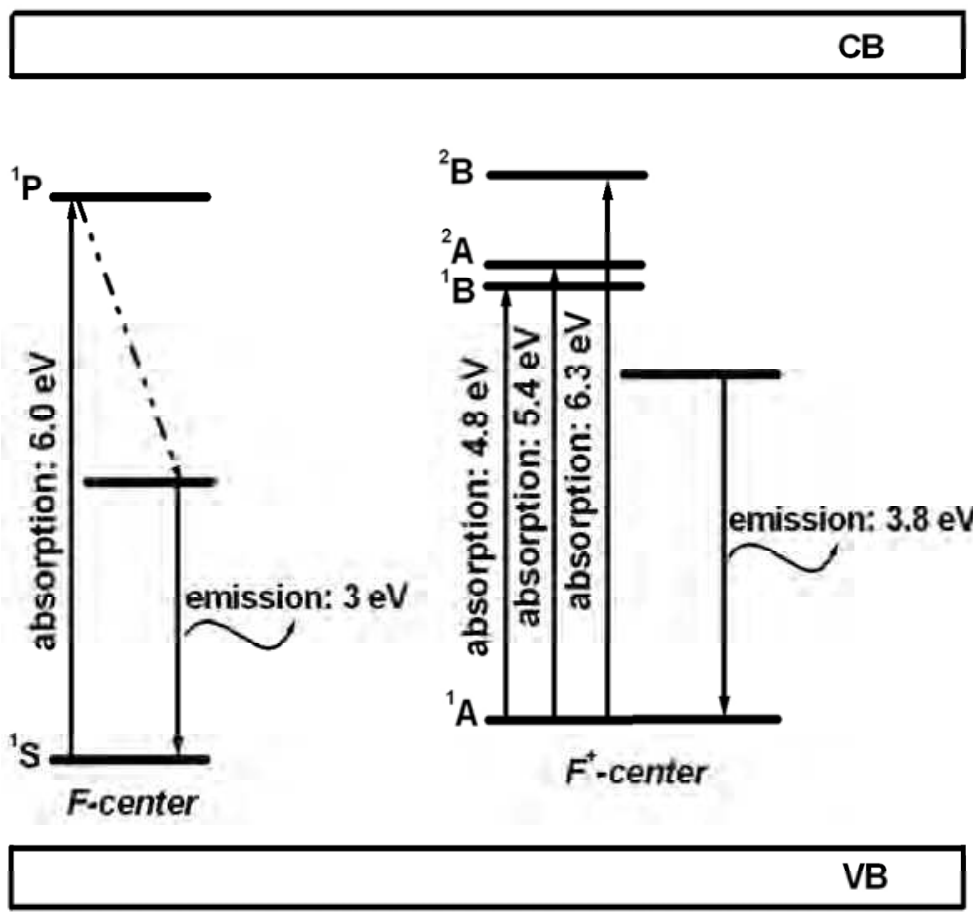

Fig. 10. Schematic energy level diagram for absorption and emission of $\mathrm{F}$ - and $\mathrm{F}^{+}$-centres in a- $\mathrm{Al}_{2} \mathrm{O}_{3}$ crystal.

In Ref. (Evans, 1994), synthetic sapphire single crystals grown by four different techniques all showed an anisotropic $5.4 \mathrm{eV}(230 \mathrm{~nm})$ absorption broad band. There was not any other absorption band presented in his cases. As for the nanometer-sized $\mathrm{Al}_{2} \mathrm{O}_{3}$ powder apart from normal lattice vacancy-type defects such as the $\mathrm{F}_{-}, \mathrm{F}^{+}$- and $\mathrm{F}_{2}$-type centers it also has the surface defect because the nanometer powder has a larger specific surface area and there exists a lot of dangling bonds in the surface.

Experimental measurements of absorption and luminescence energies for single-vacancy and for dimer centers in $\mathrm{Al}_{2} \mathrm{O}_{3}$ are collected in Table 5 .

\begin{tabular}{|c|c|c|}
\hline & Absorption & Luminescence \\
\hline F center & 6.0 & 3.00 \\
\hline $\mathrm{F}^{+}$center & $6.3,5.4,4.8$ & 3.80 \\
\hline $\mathrm{F}_{2}$ & 4.1 & 2.40 \\
\hline$F_{2}^{+}$ & 3.5 & 3.26 \\
\hline$F_{2}^{2+}$ & 2.7 & 2.22 \\
\hline
\end{tabular}

Table 5. Experimental measurements of optical properties for single-vacancy and for dimer centers in $\mathrm{Al}_{2} \mathrm{O}_{3}$, energies are in $\mathrm{eV}$ (Crawford, 1984; Evans et al., 1994). 
The band of F-centers is absent in both samples due to the existence of impurity $\mathrm{Cr}$ (Aoki, 1996). For instance, the CL intensity at $3.81 \mathrm{eV}\left(\mathrm{F}^{+}\right.$-center) of the $\mathrm{a}-\mathrm{Al}_{2} \mathrm{O}_{3}$ formed from gibbsite is approximately 5 times higher than that of the a- $\mathrm{Al}_{2} \mathrm{O}_{3}$ formed from PM2000 measured under the same excitation conditions. The main specific feature of the CL spectra of the $\mathrm{a}-\mathrm{Al}_{2} \mathrm{O}_{3}$ is the presence of a new emission band with the maximum at $3.32 \mathrm{eV}$. It is a possible that the new emission band is related to surface $F_{\mathrm{s}}$-centers concentrating on nanoparticle boundaries (Evans, 1995).

Luminescence spectra obtained for anion-deficient aluminum corundum exposed to different types of excitation and stimulation exhibit luminescence with nanosecond $\left(\mathrm{F}^{+}-\right.$ centers), microsecond $\left(\mathrm{Ti}^{3+}\right.$ and $\left.\mathrm{Al}^{+}{ }_{\mathrm{i}}\right)$ and millisecond $\left(\mathrm{F}\right.$ and $\mathrm{Cr}^{3+}$ ) decay times (Surdo et al., 2005). Significantly, the aforementioned centers, which actively participate in relaxation processes, have considerably different decay times $t$ and emission band maxima $h v$ (Table 6).

\begin{tabular}{|c|c|c|c|c|c|}
\hline Parameter & $\mathrm{F}^{+}$ & $\mathrm{F}$ & $A l_{i}^{+}$ & $\mathrm{Cr}^{3+}$ & $\mathrm{Ti}^{3+}$ \\
\hline$h v(\mathrm{eV})$ & 3.8 & 3.0 & 2.4 & 1.79 & 1.75 \\
\hline$\tau$ & $2 \mathrm{~ns}$ & $34 \mathrm{~ms}$ & $56 \mu \mathrm{s}$ & $4 \mathrm{~ms}$ & $3.5 \mu \mathrm{s}$ \\
\hline
\end{tabular}

Table 6. Basic parameters of the emission of most active centers (Surdo et al., 2001; Springis \& Valbis, 1984)

The band $487 \mathrm{~nm}(2.54 \mathrm{eV})$ can be related to the aggregate $\mathrm{F}_{2}$-centers produced by doubleoxygen vacancies and the centers formed by interstitial aluminum ions. It is known that these centers are responsible for the green luminescence in highly disordered crystals of aluminum oxide (Tale et al., 1996; Springis \& Valbis, 1984).

\subsection{2 $\mathrm{Cr}^{3+}$ in $\mathrm{Al}_{2} \mathrm{O}_{3}$}

A classic example of the isolated luminescent centre is $\mathrm{Cr}^{3+}$ in $\mathrm{Al}_{2} \mathrm{O}_{3}$ (ruby) when the excited electronic energy levels of the host are at much higher energy than those of the dopant ion. The dopant ion colours the colourless host lattice red. If the concentration of the dopant ion is low, the interaction between the dopant ions can be neglected. This is what we consider here as an isolated luminescent centre.

Different impurities in corundum $\left(a-\mathrm{Al}_{2} \mathrm{O}_{3}\right)$ produce different color varieties. All colors of corundum are referred to as sapphire, except for the red color, which is known as ruby. Corundum has a trigonal lattice $\mathrm{D}_{3 \mathrm{~d}}$ structure. The crystals have an approximately hexagonal closed packing structure of oxygen and metal atoms. The six oxygen ions are octahedrally coordinated cations; and only two-thirds of the octahedral sites are filled. If corundum has more than $1000 \mathrm{ppm} \mathrm{Cr}^{3+}$ ions as impurities, it is referred to as a ruby. Rubies can be used in solid-state lasers (Soukieh et al., 2004), and they fetch high prices in gem markets. Chromium can be substituted for the aluminum in corundum and is present as chromium oxide. The $\mathrm{Cr}^{3+}$ ion is slightly larger than $\mathrm{Al}^{3+}$; therefore, it naturally enters easily into the corundum structure. As a result, $\mathrm{Cr}^{3+}$ ions form $3 \mathrm{~d}^{3}$, with only three unpaired electrons in the $3 \mathrm{~d}$ orbitals. If the $\mathrm{Cr}^{3+}$ ion is located in the $\mathrm{Al}^{3+}$ site in corundum, it coordinates the six oxygens into a distorted octahedral configuration (Nassau, 1983). 
According to the ligand field theory (Figgis et al., 2000), splitting of the $3 \mathrm{~d}^{3}\left(\mathrm{Cr}^{3+}\right)$ orbital should result in the spectroscopic terms ${ }^{4} \mathrm{~A}_{2}\left(A\right.$ : no degeneracy) $,{ }^{4} \mathrm{~T}_{2},{ }^{4} \mathrm{~T}_{1}$ ( $T$ : three fold degeneracy), and ${ }^{2} \mathrm{E}$ ( $E$ : two fold degeneracy).

For $\mathrm{Cr}^{3+}$ in $\mathrm{Al}_{2} \mathrm{O}_{3}$ crystal, $\mathrm{Cr}^{3+}$ substitutes for some of $\mathrm{Al}^{3+}$, and adopts octahedral ligand coordination. The $3 \mathrm{~d}$ levels are extremely host sensitive. The strong crystal field in $\mathrm{Al}_{2} \mathrm{O}_{3}$ leads to the splitting of $3 \mathrm{~d}$ electron orbits of $\mathrm{Cr}^{3+}$ and produces the ground level: ${ }^{4} \mathrm{~A}_{2}$, and the excited states: ${ }^{2} \mathrm{E}, \mathrm{T}_{2}$, and ${ }^{4} \mathrm{~T}_{1}$, etc. the transitions from ${ }^{4} \mathrm{~A}_{2}$ to ${ }^{4} \mathrm{~T}_{2}$, and ${ }^{4} \mathrm{~T}_{1}$ are spin-allowed, so these energy levels act as broad pumping levels. The ${ }^{2} \mathrm{E}$ is the narrow lowest excited band, acting as emitting level. The unusual magnitude of this crystal field splitting extends the lowest ${ }^{2} \mathrm{E}$ state $14400 \mathrm{~cm}^{-1}(694 \mathrm{~nm})$ above the ground state. Thus the ${ }^{2} \mathrm{E}-{ }^{4} \mathrm{~A}_{2}$ transition of $\mathrm{Cr}^{3+}: \mathrm{Al}_{2} \mathrm{O}_{3}$ crystal lies in visible spectral region. Exciting any of the pumping bands of ${ }^{4} \mathrm{~T}_{2}$, and ${ }^{4} \mathrm{~T}_{1}$ results in fast relaxation to lowest ${ }^{2} \mathrm{E}$ excited state. At room temperature, the fluorescence emitting from ${ }^{2} \mathrm{E}$ state appears as a sharp band with a peak at $694 \mathrm{~nm}$ corresponding to the transition to the ${ }^{2} \mathrm{E}$ terminal state. The $\mathrm{Cr}^{3+}$ ion has two strong absorption bands in the visible part of the spectrum, which explain the red color, i.e., $2.2 \mathrm{eV}$ light can be absorbed to raise the chromium from the ${ }^{4} \mathrm{~A}_{2}$ ground level to the ${ }^{4} \mathrm{~T}_{2}$ excited level as absorption in the yellow-green, and $3.0 \mathrm{eV}$ light raises it to the ${ }^{4} \mathrm{~T}_{1}$ level as violet absorption. In addition, the absorption decreases to zero in the red region below $2.0 \mathrm{eV}$. Therefore, rubies have a red color with a slight purple overtone.

Chromium impurity in $\mathrm{a}-\mathrm{Al}_{2} \mathrm{O}_{3}$ lattice is characterised by two bands of absorption (3.1 and $2.2 \mathrm{eV})$ and one fine emission structure peaked at $1.8 \mathrm{eV}(693 \mathrm{~nm})$ as summarised in Fig. 11.

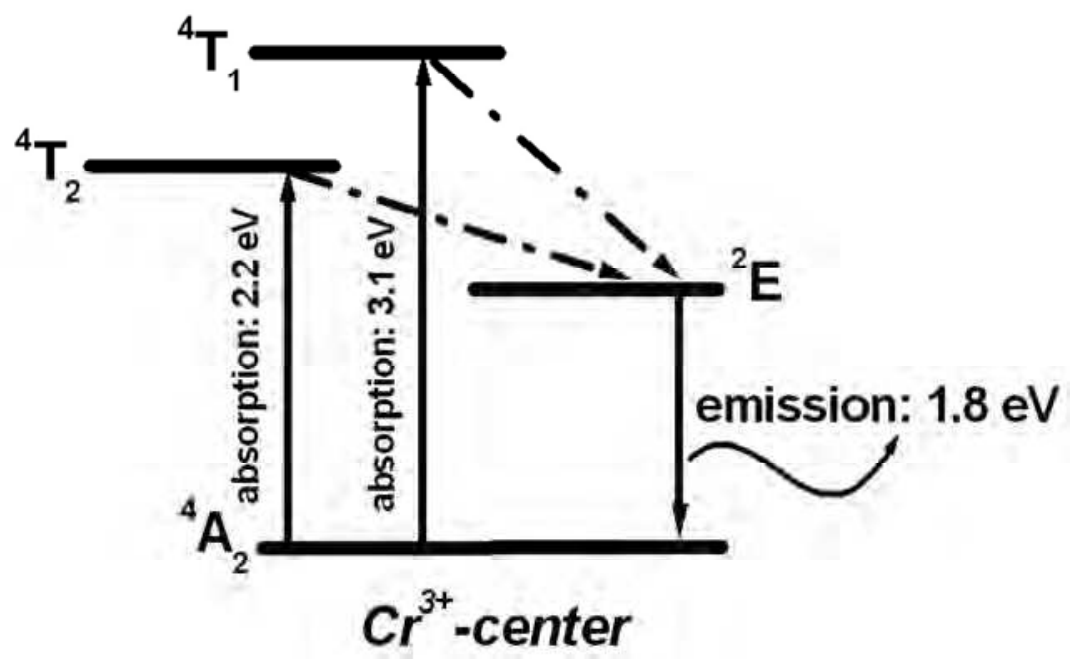

Fig. 11. Schematic energy level diagram for absorption and emission of $\mathrm{Cr}^{3+}$-center in $\mathrm{a}-$ $\mathrm{Al}_{2} \mathrm{O}_{3}$ crystal. 
In oxide insulators, a number of transition metal and rare earth impurities act as luminescence centers. The trivalent chromium ion $\left(\mathrm{Cr}^{3+}\right)$, with electronic configuration $3 \mathrm{~d}^{3}$, is an efficient luminescence center in many light-metal oxides, including $\mathrm{Al}_{2} \mathrm{O}_{3}$ and $\mathrm{MgO}$. The trivalent chromium ion enters substitutionally and is surrounded by an octahedron of oxygen ions. In aluminum oxide, the surroundings of the chromium ion are not quite cubic, as the oxygen octahedron is stretched along its trigonal symmetry axis $\mathrm{C}_{3}$.

Chromium in $\mathrm{a}-\mathrm{Al}_{2} \mathrm{O}_{3}$ lattice gives a luminescence in the visible domain. In $\mathrm{CL}$, the narrow band at $693 \mathrm{~nm}$ is attributed to chromium impurity (Ghamnia et al., 2003). In $\mathrm{Al}_{2} \mathrm{O}_{3}: \mathrm{Cr}^{3+}$ (ruby) the apparent lifetime of the R-line emission may increase from the intrinsic value of $3.8 \mathrm{~ms}$ up to $12 \mathrm{~ms}$ (Auzel \& Baldacchini, 2007).

The typical CL spectra of $\mathrm{a}-\mathrm{Al}_{2} \mathrm{O}_{3}$, formed by calcination of gibbsite powder at $1573 \mathrm{~K}$ for 24 $\mathrm{h}$ (black line) and by oxidation of PM2000 at 1223K for $72 \mathrm{~h}$ (red line), obtained in the region of 600 to $800 \mathrm{~nm}$ at room temperature are shown in Fig. 12. The sharp band at $693 \mathrm{~nm}(1.79$ $\mathrm{eV})$, with a radiative lifetime $\tau_{\mathrm{R}} \sim 4 \mathrm{~ms}$ (de Wijn, 2007), as well as features at $706 \mathrm{~nm}(1.76 \mathrm{eV})$ and $713 \mathrm{~nm}(1.74 \mathrm{eV})$ undoubtedly belongs to $\mathrm{Cr}^{3+}$ emission in a-alumina, and the subband at $677 \mathrm{~nm}(1.83 \mathrm{eV})$ is attributed to the ${ }^{2} \mathrm{E}-{ }^{4} \mathrm{~A}_{2}$ transition of $\mathrm{Mn}^{4+}$ ions in $\mathrm{Al}_{2} \mathrm{O}_{3}$ (Jovanic, 1997; Geschwind et al., 1962; Crozier, 1965).

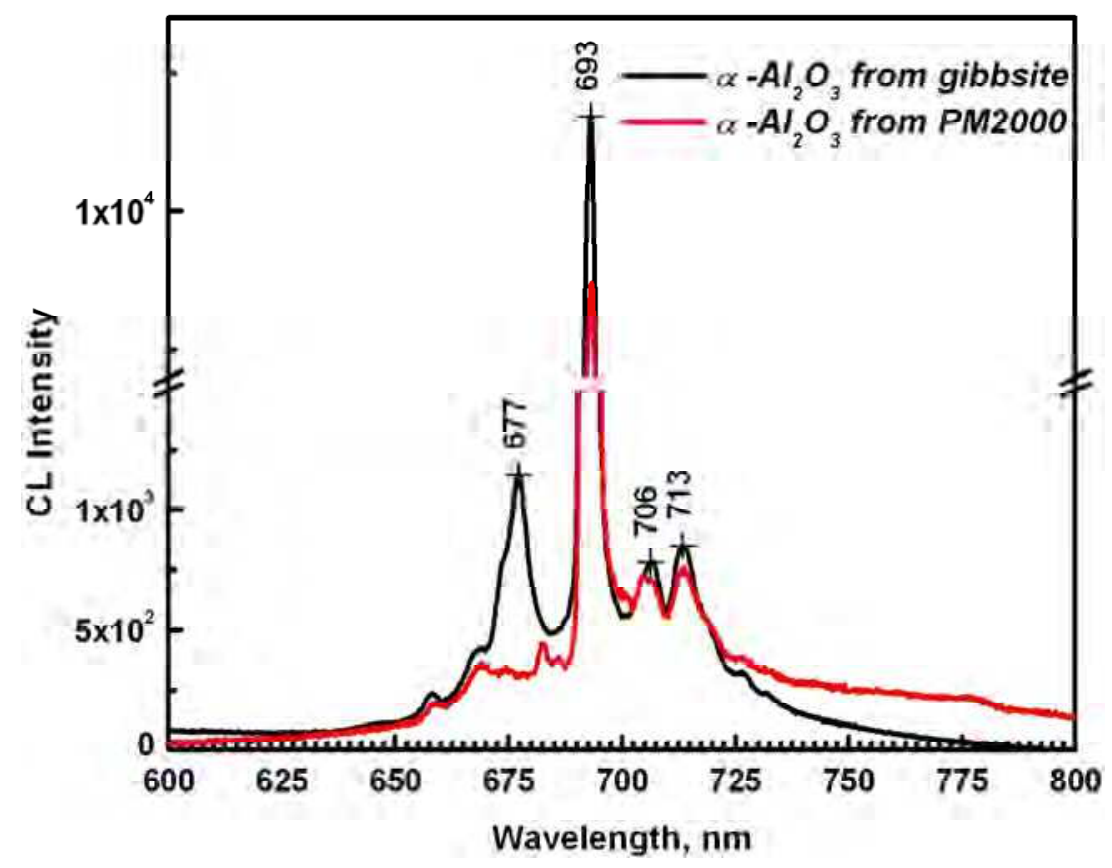

Fig. 12. CL spectra of $\mathrm{a}-\mathrm{Al}_{2} \mathrm{O}_{3}$, formed by calcination of gibbsite powder at $1573 \mathrm{~K}$ for $24 \mathrm{~h}$ (black line) and by oxidation of PM2000 at $1223 \mathrm{~K}$ for $72 \mathrm{~h}$ (red line), obtained in the region of 600 to $800 \mathrm{~nm}$ at room temperature. 
$\mathrm{Mn}^{4+}$ is known to emit doublet lines at 672 and $676 \mathrm{~nm}$ in $\mathrm{a}-\mathrm{Al}_{2} \mathrm{O}_{3}$ (Kulinkin et al., 2000).

A similar emission was recently reported in $\mathrm{a}^{-} \mathrm{Al}_{2} \mathrm{O}_{3}$ microcones ( $\mathrm{Li}$ et al., 2010). Thus, it can be concluded that the incorporation of $\mathrm{Mn}^{4+}$ ions in $\mathrm{a}-\mathrm{Al}_{2} \mathrm{O}_{3}$ observed in the experiment is irreversible and occurs during its formation from the $\mathrm{Mn}^{4+}$ ions dissolved quite uniformly in the bulk of the low-temperature polymorphic modifications of alumina (gibbsite $\rightarrow \mathrm{X}-\rightarrow \mathrm{K}-$ $\rightarrow \mathrm{a}-\mathrm{Al}_{2} \mathrm{O}_{3}$ ). The $\mathrm{Mn}^{4+}$ impurity emission at $677 \mathrm{~nm}$ is absent in a-alumina films obtained by oxidation of a metallic FeCrAl alloy. Taking into account high sensitivity of the method, this indicates very low concentration of such ions.

\section{Conclusion}

$\mathrm{a}-\mathrm{Al}_{2} \mathrm{O}_{3}$ was prepared either by calcination of gibbsite and also generated by oxidation of a metallic FeCrAl alloy. The $\mathrm{Mn}^{4+}$ impurity emission at $1.83 \mathrm{eV}$ is absent in a-alumina thin films obtained by oxidation of a metallic FeCrAl alloy. The band of F-centers is absent in both samples due to the existence of impurity $\mathrm{Cr}$. The difference in oxygen vacancies $\left(\mathrm{F}^{+}-\right.$ centers) amount between $\mathrm{a}-\mathrm{Al}_{2} \mathrm{O}_{3}$ from gibbsite and from PM2000 was confirmed by CL spectra.

\section{References}

Aoki, Y.; My, N. T.; Yamamoto, S. \& Naramoto, H. (1996). Luminescence of sapphire and ruby induced by $\mathrm{He}$ and Ar ion irradiation. Nuclear Instruments and Methods in Physics Research Section B, Vol.114, No.3-4, (July 1996), pp. 276-280, ISSN 0168$583 \mathrm{X}$

Auzel, F. \& Baldacchini, G. (2007). Photon trapping in ruby and lanthanide-doped materials: Recollections and revival. Journal of Luminescence, Vol.125, No.1-2, (July-August 2007), pp. 25-30, ISSN 0022-2313

Barker, Jr, A.S. (1963). Infrared lattice vibrations and dielectric dispersion in corundum. Physical Review, Vol.132, No.4, (November 1963), pp. 1474-1481, ISSN 0031$899 X$

Boumaza, A. \& Djelloul, A. (2010). Estimation of the intrinsic stresses in a-alumina in relation with its elaboration mode. Journal of Solid State Chemistry, Vol.183, No.5, (May 2010), pp. 1063-1070, ISSN 0022-4596

Boumaza, A.; Djelloul, A. \& Guerrab, F. (2010). Specific signatures of a-alumina powders prepared by calcination of boehmite or gibbsite. Powder Technology, Vol.201, No.2, (July 2010), pp. 177-180, ISSN 0032-5910

Brewer, J.D.; Jeffries, B.T. \& Summers, G.P. (1980). Low-temperature fluorescence in sapphire. Physical Review B condensed matter and Materials Physics Vol.22, No.10, (November 1980), pp. 4900-4906, ISSN 1098-0121

Brindley, G.W. \& Choe, J.O. (1961). Reaction series gibbsite $\rightarrow$ chi alumina $\rightarrow$ kappa alumina $\rightarrow$ corundum. American Mineralogist, Vol.46, No.7-8, (July-August 1961), pp. 771-785, ISSN 0003-004X

Crawford Jr., J.H. (1984). Defects and defect processes in ionic oxides: Where do we stand today?. Nuclear Instruments and Methods in Physics Research Section B, Vol.1, No.2-3, (February 1984), pp. 159-165, ISSN 0168-583X 
Crozier, M.H. (1962). Optical Zeeman effect in the $\mathrm{R}_{1}$ and $\mathrm{R}_{2}$ lines of $\mathrm{Mn}^{4+}$ in $\mathrm{Al}_{2} \mathrm{O}_{3}$. Physics Letters, Vol.18, No.3, (September 1965), pp. 219-220, ISSN 0031-9163

de Wijn, H.W. (2007). Phonon physics in ruby studied by optical pumping and luminescence. Journal of Luminescence, Vol.125, No.1-2, (July-August 2007), pp. 5559, ISSN 0022-2313

Evans, B.D.; Pogatshnik, G.J. \& Chen, Y. (1994). Optical properties of lattice defects in a$\mathrm{Al}_{2} \mathrm{O}_{3}$. Nuclear Instruments and Methods in Physics Research Section B, Vol.91, No.1-4, (June 1994), pp. 258-262, ISSN 0168-583X

Evans, B.D. (1994). Ubiquitous blue luminescence from undoped synthetic sapphires. Journal of Luminescence. Vol.60-61, (April 1994), pp. 620-626, ISSN 0022-2313

Evans, B.D. (1995). A review of the optical properties of anion lattice vacancies, and electrical conduction in $\mathrm{a}-\mathrm{Al}_{2} \mathrm{O}_{3}$ : their relation to radiation-induced electrical degradation. Journal of Nuclear Materials, Vol.219, (March 1995), pp. 202-223, ISSN 0022-3115

Figgis, B.N. \& Hitchman, M.A. (2000). Ligand Field Theory and its Applications, John Wiley \& Sons Inc, ISBN 978-0-471-31776-0, New York

Geschwind, S.; Kisliuk, P.; Klein, M.P.; Remeika, J.P. \& Wood, D.L. (1962). Sharp-Line Fluorescence, Electron Paramagnetic Resonance, and Thermoluminescence of $\mathrm{Mn}^{4+}$ in $a-\mathrm{Al}_{2} \mathrm{O}_{3}$. Physical Review, Vol.126, No.5, (June 1962), pp. 1684-1686, ISSN 0031$899 \mathrm{X}$

Ghamdi, A. Al. \& Townsend, P.D. (1990). Ion beam excited luminescence of sapphire. Nuclear Instruments and Methods in Physics Research B, Vol.46, No.1-4, (February 1990), pp. 133-136, ISSN 0168-583X

Ghamnia, M.; Jardin, C. \& Bouslama, M. (2003). Luminescent centres F and $\mathrm{F}^{+}$in aalumina detected by cathodoluminescence technique. Journal of Electron Spectroscopy and Related Phenomena, Vol.133, No.1-3, (November 2003), pp. 5563, ISSN 0368-2048

Golightly, F.A.; Stott, F.H. \& Wood, G.C. (1979). The Relationship Between Oxide Grain Morphology and Growth Mechanisms for Fe-Cr-Al and Fe-Cr-Al-Y Alloys. Journal of The Electrochemical Society, Vol.126, No.6, (June 1979), pp. 1035-1042, ISSN 00134651

Hou, P.Y.; Zhang, X.F. \& Cannon, R.M. (2004). Impurity distribution in $\mathrm{Al}_{2} \mathrm{O}_{3}$ formed on an FeCrAl alloy. Scripta Materialia, Vol.50, No.1, (January 2004) pp. 45-49, ISSN 13596462

http:/ / accuratus.com/alumox.html/ Aluminum Oxide, $\mathrm{Al}_{2} \mathrm{O}_{3}$ Material Characteristics

Jheeta, K.S.; Jain, D.C.; Fouran Singh; Ravi Kumar \& Garg, K.B. (2006). Photoluminescence and UV-vis studies of pre- and post-irradiated sapphire with $200 \mathrm{MeV} \mathrm{Ag}^{8+}$ ions. Nuclear Instruments and Methods in Physics Research B, Vol.244, No.1, (March 2006), pp. 187-189, ISSN 0168-583X(02)

Jovanic, B.R. (1997). Shift under pressure of the luminescence transitions of corundum doped with $\mathrm{Mn}^{4+}$. Journal of Luminescence, Vol.75, No.2, (September 1997), pp. 171174, ISSN 0022-2313 
Kislov, A.N.; Mazurenko, V.G.; Korzov, K.N. \& Kortov, V.S. (2004). Interionic potentials and localized vibrations in $\mathrm{Al}_{2} \mathrm{O}_{3}$ crystals with vacancies. Physica B: Condensed Matter, Vol.352, No.1-4, (October 2004), pp. 172-178, ISSN 0921-4526

Kogure, T. (1999). Dehydration sequence of gibbsite by electron beam irradiation in a TEM. Journal of the American Ceramic Society, Vol. 82, No.3, (March 1999), pp. 716-720, ISSN 0002-7820

Kortov, V.S.; Ermakov, A.E.; Zatsepin, A.F. \& Nikiforov, S.V. (2008). Luminescence properties of nanostructured alumina ceramic. Radiation Measurements, Vol.43, No.2-6, (February-June 2008), pp. 341-344, ISSN 1350-4487

Kortov, V. \& Milman, I. (1996). Some New Data on Thermoluminescence Properties of Dosimetric Alpha- $\mathrm{Al}_{2} \mathrm{O}_{3}$ Crystals. Radiation Protection Dosimetry, Vol.65, No.1-4, (June 1996), pp. 179-184, ISSN 0144-8420

Kulinkin, A. B.; Feofilov, S. P. \& Zakharchenya, R. I. (2000). Luminescence of impurity $3 d$ and $4 f$ metal ions in different crystalline forms of $\mathrm{Al}_{2} \mathrm{O}_{3}$. Physics of the Solid State, Vol.42, No.5, (May 2000), pp. 857-860, ISSN 1063-7834

La, S.; Bartram, R.H. \& Cox, R.T. (1973). The $F^{+}$center in reactor-irradiated aluminum oxide . Journal of Physics and Chemistry of Solids, Vol.34, No.6, (June 1973), pp. 1079-1086, ISSN 0022-3697

Li, P.G.; Lei, M. \& Tang, W.H. (2010). Raman and photoluminescence properties of $\alpha-\mathrm{Al}_{2} \mathrm{O}_{3}$ microcones with hierarchical and repetitive superstructure. Materials Letters, Vol.64, No.2, (January 2010), pp. 161-163, ISSN 0167-577X

Ma, C.; Chang, Y.; Ye, W.; Shang, W. \& Wang, C. (2008). Supercritical preparation of hexagonal $\gamma$-alumina nanosheets and its electrocatalytic properties. Journal of Colloid and Interface Science, Vol.317, No.1, (January 2008), pp. 148-154, ISSN 00219797

MacKenzie, K.J.D.; Temuujin, J. \& Okada, K. (1999). Thermal decomposition of mechanically activated gibbsite. Thermochimica Acta, Vol.327, No.1-2, (March 1999), pp. 103-108, ISSN 0040-6031

Mennicke, C.; Schumann, E.; Ruhle, M.; Hussey, R.J.; Sproule, G.I. \& Graham, M.J. (1998). The Effect of Yttrium on the Growth Process and Microstructure of $\mathrm{a}-\mathrm{Al}_{2} \mathrm{O}_{3}$ on FeCrAl. Oxidation of metals, Vol.49, No.5-6, (June 1998), pp. 455-466, ISSN 0030$770 \mathrm{X}$

Michizono, S.; Saito, Y.; Suharyanto; Yamano, Y. \& Kobayashi, S. (2007). Surface characteristics and electrical breakdown of alumina materials. Vacuum, Vol.81, No.6, (February 2007), pp. 762-765, ISSN 0042-207X

Monteiro, T.; Boemare, C.; Soares, M.J.; Alves, E.; Marques, C.; McHargue, C.; Ononye, L.C. \& Allard, L.F. (2002). Luminescence and structural studies of iron implanted a$\mathrm{Al}_{2} \mathrm{O}_{3}$. Nuclear Instruments and Methods in Physics Research Section B: Beam Interactions with Materials and Atoms, Vol.191, No.1-4, (May 2002), pp. 638-643, ISSN 0168-583(2)

Nassau, K. (1983). The Physics and Chemistry of Color: The Fifteen Causes of Color, John Wiley \& Sons Inc, ISBN 0471867764, NewYork 
Ollivier, B.; Retoux, R.; Lacorre, P.; Massiot, D. \& Férey, G. (1997). Crystal Structure of Kappa Alumina an X-Ray powder diffraction, TEM and NMR study. Journal of Materials Chemistry, Vol.7, No.6, (1997), pp. 1049- 1056, ISSN 0959-9428

Oster, L.; Weise, D. \& Kristiapoller, N. (1994). A study of photostimulated thermoluminescence in C-doped alpha $-\mathrm{Al}_{2} \mathrm{O}_{3}$ crystals. Journal of Physics D: Applied Physics, Vol.27, No.8, (August 1994), pp. 1732-1736, ISSN 0022-3727

Przybylski, K.; Garrett-Reed, A.J.; Pint, B.A.; Katz, E.P. \& Yurek, G.J. (1987). Segregation of Y to Grain Boundaries in the $\mathrm{Al}_{2} \mathrm{O}_{3}$ Scale Formed on an ODS Alloy. Journal of The Electrochemical Society, Vol.134, No.12, (December 1987), pp. 3207-3208, ISSN 00134651

Quadakkers, W.J.; Elschner, A.; Speier, W. \& Nickel, H. (1991). Composition and growth mechanisms of alumina scales on FeCrAl-based alloys determined by SNMS. Applied Surface Science, Vol.52, No.4, (December 1991), pp. 271-287, ISSN 01694332

Rodríguez-Carvajal, J. (1993). Recent Advances in Magnetic Structure Determination by Neutron Powder Diffraction. Physica B Condensed Matter, Vol. 192, No. 1-2, (October 1993), pp. 55-69, ISSN 0921-4526

Saalfeld, H. \& Wedde, M. (1974). Refinement of the structure of gibbsite, $\mathrm{Al}(\mathrm{OH}) 3$. Zeitschrift für Kristallographie, Vol.139, No.1-2, (April 1974), pp. 129-135, ISSN 0044-2968

Saalfeld, H.N. (1960). Strukturen des Hydrargillitis und der Zwis- chenstufen biem Entwassern. Neues Jahrbuch für Mineralogie, Vol.95, No.7-8, (1960), pp. 1-87, ISSN 0077-7757

Soukieh, M.; Ghani, B.A. \& Hammadi, M. (2004). Numerical calculations of intracavity dye Q-switched ruby laser. Optics and Lasers in Engineering, Vol.41, No.1, (January 2004), pp. 177-187, ISSN 0143-8166

Springis, M.J. \& Valbis, J.A. (1984). Visible luminescence of colour centres in sapphire. Physica status solidi. B, Vol.123, No.1, (May 1984), pp. 335-343, ISSN 0370-1972

Stumpf, H.C.; Russel, A.S.; Newsome, J.W. \& Tucker, C.M. (1950). Thermal transformations aluminas and alumina hydrates - Reaction with $44 \%$ Technical Acid, Industrial \& Engineering Chemistry Research, Vol.42, No.7, (July 1950), pp. 1398-1403, ISSN 08885885

Surdo, A.I.; Kortov, V.S. \& Pustovarov, V.A (2001). Luminescence of F and $\mathrm{F}^{+}$centers in corundum upon excitation in the interval from 4 to $40 \mathrm{eV}$. Radiation Measurements, Vol.33, No.5, (October 2001), pp. 587-591, ISSN 1350-4487

Surdo, A.I.; Pustovarov, V.A.; Kortov, V.S.; Kishka, A.S. \& Zinin, E.I. (2005). Luminescence in anion-defective $\mathrm{a}-\mathrm{Al}_{2} \mathrm{O}_{3}$ crystals over the nano-, micro- and millisecond intervals. Nuclear Instruments and Methods in Physics Research A, Vol.543, No.1, (May 2005), pp. 234-238, ISSN 0168-9002

Tale, I.; Piters, T.M.; Barboza-Flores, M.; Perez-Salas, R.; Aceves, R. \& Springis, M. (1996). Optical Properties of Complex Anion Vacancy Centres and Photo-Excited Electronic Processes in Anion Defective Alpha- $\mathrm{Al}_{2} \mathrm{O}_{3}$. Radiation Protection Dosimetry, Vol.65, No.1-4, (June 1996), pp. 235-238, ISSN 0144-8420 
Whittington, B. \& Ilievski, D. (2004). Determination of the gibbsite dehydration reaction pathway at conditions relevant to Bayer refineries. Chemical Engineering Journal, Vol.98, No.1-2, (March 2004), pp. 89-97, ISSN 1385-8947

Wood, G. C. (1970). High-temperature oxidation of alloys. Oxidation of Metals, Vol.2, No.1, (March 1970), pp. 11-57, ISSN 0030-770X

Yu, Z.Q.; Li, C.\& Zhang, N. (2002). Size dependence of the luminescence spectra of nanocrystal alumina. Journal of Luminescence. Vol.99, No.1, (August 2002), pp. 2934, ISSN 0022-2313 


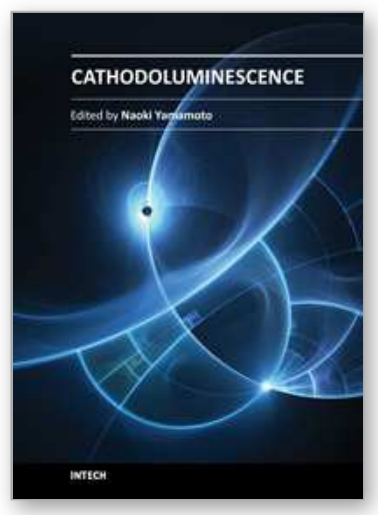

\author{
Cathodoluminescence \\ Edited by Dr. Naoki Yamamoto
}

ISBN 978-953-51-0362-2

Hard cover, 324 pages

Publisher InTech

Published online 28, March, 2012

Published in print edition March, 2012

Cathodoluminescence $(\mathrm{CL})$ is a non-destructive technique to characterize optical and electronic properties of nanostructures in many kinds of materials. Major subject is to investigate basic parameters in semiconductors, impurities in oxides and phase determination of minerals. CL gives information on carrier concentration, diffusion length and life time of minority carriers in semiconductors, and impurity concentration and phase composition in composite materials. This book involves 13 chapters to present the basics in the $\mathrm{CL}$ technique and applications to particles, thin films and nanostructures in semiconductors, oxides and minerals. The chapters covered in this book include recent development of $C L$ technique and applications to wide range of materials used in modern material science.

\title{
How to reference
}

In order to correctly reference this scholarly work, feel free to copy and paste the following:

Djelloul Abdelkader and Boumaza Abdecharif (2012). Peculiarity of the Cathodoluminescence of Ipha- Alumina Prepared by Calcination of Gibbsite Powder or Generated by Oxidation of a Metallic FeCrAl Alloy, Cathodoluminescence, Dr. Naoki Yamamoto (Ed.), ISBN: 978-953-51-0362-2, InTech, Available from: http://www.intechopen.com/books/cathodoluminescence/peculiarity-of-the-cathodoluminescence-of-aluminaprepared-by-calcination-of-gibbsite-powder-or-gene

\section{INTECH}

open science | open minds

\author{
InTech Europe \\ University Campus STeP Ri \\ Slavka Krautzeka 83/A \\ 51000 Rijeka, Croatia \\ Phone: +385 (51) 770447 \\ Fax: +385 (51) 686166 \\ www.intechopen.com
}

\author{
InTech China \\ Unit 405, Office Block, Hotel Equatorial Shanghai \\ No.65, Yan An Road (West), Shanghai, 200040, China \\ 中国上海市延安西路65号上海国际贵都大饭店办公楼 405 单元 \\ Phone: +86-21-62489820 \\ Fax: $+86-21-62489821$
}


(C) 2012 The Author(s). Licensee IntechOpen. This is an open access article distributed under the terms of the Creative Commons Attribution 3.0 License, which permits unrestricted use, distribution, and reproduction in any medium, provided the original work is properly cited. 